\title{
Inventory and Monitoring of California Islands Candidate Plant Taxa
}

\author{
Principal Investigators: \\ Kathryn McEachern \\ Dieter Wilken \\ Katherine A. Chess \\ Final Report to Species at Risk Program \\ U.S. Geological Survey \\ February 26, 1997
United States Department of Interior United States Geological Survey Biological Resources Division Western Ecological Research Center Channel Islands Field Station 1901 Spinnaker Dr. Ventura, California 93001




\title{
U.S. DEPARTMENT OF THE INTERIOR BRUCE BABBITT, Secretary
}

\author{
U.S. GEOLOGICAL SURVEY \\ Charles G. Groat, Director
}

The use of firm, trade, and brand names in this report is for identification purposes only and does not constitute endorsement by the U.S. Geological Survey

For additional information write to:

Distsrict Chief

U.S. Geological Survey

Placer Hall, Suite 2012

$6000 \mathrm{~J}$ Street

Sacramento, CA 95819-6129
Copies of this report can be purchased from:

U.S. Geological Survey

Information Services

Box 25286

Federal Center

Denver, CO 80225 


\section{TABLE OF CONTENTS}

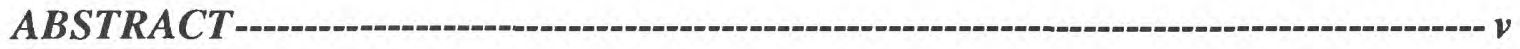

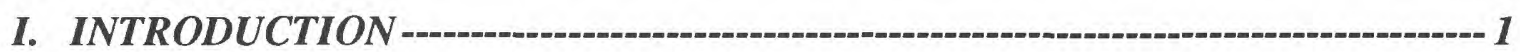

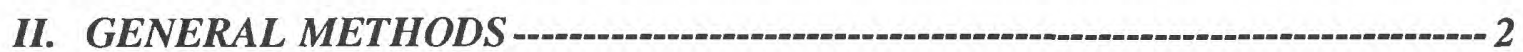

Taxa studied - 2

Channel Islands rare plant database development-_ 2

Ground surveys -

Population census counts-_-_-3

Reproductive biology -4

Data archival-_ 4

III. RESULTS AND DISCUSSION-10N

Arctostaphylos confertiflora Eastwood (Santa Rosa Island manzanita), Ericaceae - 9

Atriplex pacifica A.Nelson (south coast saltbush or saltscale), Chenopodiaceae - 10

Castilleja mollis (Pennell) (soft-leaved Indian paintbrush), Scrophulariaceae-11

Dendromecon rigida Benth. ssp. harfordii (Kellogg) Raven [synonym:

Dendromecon harfordii Kellogg ssp. harfordii], (northern island bush poppy or channel island tree poppy), Papaveraceae- 14

Dudleya candelabrum Rose (candleholder dudleya), Crassulaceae - 17

Eriogonum grande E.Greene var. rubescens (E.Greene) Munz (red buckwheat, red-flowered buckwheat), Polygonaceae - 20

Erysimum ammophilum A. A. Heller (coast wallflower), Brassicaceae-22

Erysimum insulare E. Greene ssp. insulare (island wallflower), Brassicaeae -22

Helianthemum greenei B.L.Rob (island rush-rose), Cistaceae- 24

Heuchera maxima Greene (island alumroot), Saxifragaceae -26

Jepsonia malvifolia (Greene) Small (island jepsonia), Saxifragaceae -28

Lasthenia glabrata Lindley ssp. coulteri (A. Gray) E. Greene, (Coulter goldfields), Asteraceae - 35

Lilium humboldtii Roezl \& Leichtlin ssp. ocellatum (Kellogg) Thorne (ocellated Humboldt lily), Liliaceae-_-36

Orobanche parishii (Jeps.) Heckard ssp. brachyloba Heckard (short-lobed

broom-rape) Orobanchaceae —_ 38

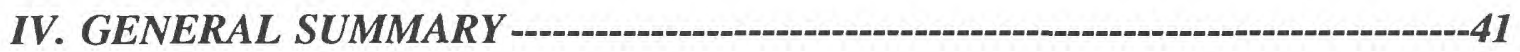

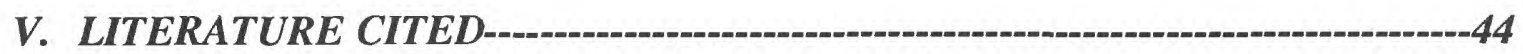




\section{LIST OF TABLES}

Table 1. California Channel Islands rare plant taxa studied 1995-1996, under NBS Species at Risk program

Table 2. Numbers of plants, flowering, and damage in Castilleja mollis plots sampled June-July 1995, Santa Rosa Island

Table 3. Numbers of plants, flowering, damage and mortality data for Castilleja mollis plots sampled June-September 1996, Santa Rosa Island $-13$

Table 4. Results of Nov. 11, 1996 census of Dudleya candelabrum south of Skunk Point, Santa Rosa Island $-18$

Table 5. Summary of Erysimum insulare ssp. insulare density, and vegetative and flowering data collected Spring 1996

Table 6. Flowing and vegetative Jepsonia malvifolia plants sampled in demography plots on Santa Cruz (SCI) and Santa Rosa (SRI) islands, Nov. 1995-Feb. 1996-_-_-.---30

Table 7. Jepsonia malvifolia seedling, vegetative and flowering plant density for plots sampled on Santa Rosa and Santa Cruz islands, February, 1996-

Table 8. Habitat cover estimated within Jepsonia malvifolia populations on Santa Rosa and Santa Cruz islands, February 1996 (mean \pm SD)

Table 9. Fruit set and pin:thrum ratios for Jepsonia malvifolia in demography plots sampled on Santa Rosa and Santa Cruz islands, November-December 1995--_-_-_-_--34

Table 10. Orobanche. parishii ssp. brachyloba density, October 11-12, 1995---_-_----40

\section{LIST OF FIGURES}

Figure 1. Santa Rosa Island, California, Coverage for rare plant surveys, November, 1996 8 
Population density and size-class sampling was done for five perennial and one annual species. Populations of the perennials are skewed toward the larger size classes. Recent recruitment was apparent only in Jepsonia malvifolia on Santa Rosa Island. Plants in study plots of three taxa on Santa Rosa showed current browsing, and trampling was evident within population boundaries of all studied populations. Deer and elk hoof scraping was a significant source of mortality to Castilleja mollis plants sampled during the Fall 1996 rutting season, and 38\% percent of Jepsonia malvifolia plots on Santa Cruz had plants that were uprooted and apparently consumed by pigs.

Reproductive biology was investigated in controlled crosses and field counts of fruit and seed set for ten taxa. Dendromecon rigida ssp. harfordii and Jepsonia malvifolia appear to be self-incompatible. Four species (Dudleya candelabrum, Eriogonum grande var. rubescens, Heuchera maxima, Lilium humboldtii ssp.

ocellatum) are apparently self-compatible, but pollination appears limited under natural conditions. Atriplex pacifica and Helianthemum greenei are self-compatible, with high rates of seed production. Reproduction in Eriogonum grande var. rubescens is apparently additionally limited by other intrinsic factors, Helianthemum greenei by the lack of ground fires, Lilium humboldtii by scarcity of pollinators, and Castilleja mollis and Orobanche parishii ssp. brachyloba by the distributions of their host plants 


\section{INTRODUCTION}

There are eight Channel Islands lying offshore from southern California, between Point Conception, at about 34.5 degrees north latitude, and the United States Mexico border at about 33 degrees. Ranging from 13 to 61 statute miles from the mainland, they vary in size from one to 96 square miles in area. None of the islands have been geologically connected to the mainland, and consequently they are rich in taxa that are either endemic to one or several islands, or to coastal southern California. The five northernmost islands (San Miguel, Santa Rosa, Santa Cruz, Anacapa, and Santa Barbara) comprise the Channel Islands National Park. They are home to more than sixty-five insular endemic plant taxa, and they support additional taxa with limited coastal mainland distributions. Population locations, sizes and conditions, general ecology and reproductive biology of most of these species is largely unknown. The National Park Service is developing Conservation Agreements and Resource Management Plans for the northern islands, in cooperation with the U.S. Fish and Wildlife Service, The Nature Conservancy, and the U.S. Navy, but it has little speciesspecific information to form the basis of management plans.

This study was funded 1995-1996 by grants from the National Biological Service's (NBS) Species at Risk program, and the National Park Service (NPS), to investigate the status and ecology of fourteen Federal category $\mathrm{C} 1$ and $\mathrm{C} 2$ plants on Santa Rosa and Santa Cruz islands. These fourteen taxa were chosen for study because they had candidate status and appeared vulnerable to effects of grazing on Santa Rosa Island (Skinner and Pavlik 1994). Santa Rosa is managed under a Special Use Permit that allows cattle, deer and elk grazing until the year 2011. For management of the grazing permit, NPS needs documentation of habitat conditions and population status under current grazing regimes. Consequently, this study focuses on plants with a significant portion of their historic distribution on Santa Rosa Island. Secondarily, these taxa have significant occurrences on Santa Cruz Island, where feral pig predation threatens the viability of vascular plant populations (Laughgrin 1994 pers. com., UC Santa Barbara; USFWS 1995). Since the funding was awarded, four of the study taxa were proposed as endangered, and the U.S. Fish and Wildlife Service dropped the "candidate category" ranking system. However, the National Park Service retains the category designations for prioritizing resource management actions. Therefore, we retain those candidate designations in this report. 


\section{GENERAL METHODS}

\section{Taxa studied}

Table 1 shows the taxa studied, their federal status, the islands where they occur and what data were collected 1994-1996. The list includes two proposed endangered and 12 taxa formerly designated by the U.S. Fish and Wildlife Service as candidate category 2 (C2) plants, now called species of federal concern. The National Park Service continues to treat these taxa as candidates for listing in their management policies. Nine of them are endemic to the Channel Islands: Arctostaphylos confertiflora, Castilleja mollis, Dendromecon rigida ssp. harfordii, Dudleya candelabrum, Eriogonum grande var. rubescens, Erysimum insulare ssp. insulare, Helianthemum greenei, Heuchera maxima, and Jepsonai malvifolia. Dendromecon rigida ssp. harfordii and Dudleya candelabrum, are endemic to Santa Rosa and Santa Cruz islands; two other species, Arctostaphylos confertiflora and Castilleja mollis, are endemic to Santa Rosa Island. The remaining five species, Atriplex pacifica, Erysimum ammophilum, Lasthenia glabrata ssp. coulteri, Lilium humboldtii ssp. ocellatum, Orobanche parishii ssp. brachyloba, occur on the islands and on the mainland (in threatened habitats).

\section{Channel Islands rare plant database development}

National Park archives, local and regional herbaria, the California Natural Diversity Database, U.S. Fish and Wildlife Service files, and the published and unpublished literature were searched for historical and current records on each of the 14 taxa. We found a wide range of information, including literature, herbarium specimens, field notes from botanist's surveys, and notes and memoranda from Channel Islands National Park staff. The information was compiled into a rare plants database of nearly 1,500 records, formatted using Microsoft Access software. When information was precise enough for us to determine where the collection or field observation was made, population locations were plotted on USGS topographic quadrangle maps of the islands. These locations are being digitized into the Arc-Info geographic information system (GIS) at Channel Islands National Park, and linked to the rare plants database. The database and GIS are available at Channel Islands National Park. The park will maintain the database as part of the integrated database for the Park's long-term ecological monitoring program.

\section{Ground surveys}

Information in the database was used to develop a search strategy for rare plants on Santa Rosa and Santa Cruz islands. Records showed that Santa Cruz Island has been fairly well surveyed in the recent past, while systematic surveys for rare plants or their habitats had never been conducted on Santa Rosa Island. Therefore, our search plan differed for the two islands. Our search strategy on Santa Rosa was to visit known (verified) population occurrences and locations that seemed likely from past field notes. Based on information in the database and our own observations, we then searched potential habitats for new occurrences of each taxon. Table 1 gives the approximate proportion of potential habitats that were covered for each taxon on Santa 
Rosa, and Figure 1 shows the areas surveyed. Some sites were difficult to access on foot and others appeared to be marginal habitats at best. Therefore, these sites were low priority on the search list and are the ones that remain to be searched. We covered the best and most likely habitats for each taxon in our surveys. On Santa Rosa Island, areas surveyed covered 7,439 hectares. Approximately 1,879 hectares remain to be surveyed in 1997 . The remaining 12,160 hectares are unlikely habitat for rare plants.

Our Santa Cruz Island surveys focused on revisiting known and putative historic locations of the taxa on our list. We did not attempt to canvas potential habitats on the entire island, as we did on Santa Rosa, because of time constraints, and because this has been done in the recent past (Hochberg et al. 1980). Santa Cruz Island terrain is extremely rugged, and some historic locations were not easily accessible on foot. Some of these locations require access by boat or helicopter, and funding constraints did not allow us to revisit them.

The search methods were the same on both islands. We visited the areas on foot, and mapped population locations on USGS topographic quadrangle maps. For each population, we recorded data on location (slope, aspect, elevation, directions to the site), population condition (approximate numbers of individuals and size classes present, evidence of disturbance or recent change in population boundaries, threats to plants), reproduction (proportion of the population flowering or setting fruit, any pollinators seen, presence of seedlings), and ecological characteristics of the habitat (associated species, amount of plant cover, substrates, moisture regimes if unusual). All observations were recorded on California Natural Diversity Database (CNDDB) forms, and sent to the CNDDB program manager in Sacramento, California. Additionally, all of our observations were entered into the Channel Islands rare plants database.

\section{Population census counts}

The mapped information was used to choose locations for more quantitative sampling of numbers and sizes of individuals in populations of five of the taxa. These taxa were chosen for sampling either because they appeared especially vulnerable to extemal threats that might be manageable by the landowners, or because virtually nothing was known about their population ecology. For taxa restricted to one or a few small areas, such as Lasthenia glabrata ssp. coulteri, each location was sampled. For taxa with a broad distribution, such as Castilleja mollis, the occupied area was stratified into 3 to 5 equal-area segments, and random locations were chosen within each segment for census sampling. Plots were placed randomly at each sample location. The number, size, and shape of plots varied for each species, depending upon individual plant size and density. All plants rooted within each plot were counted, their sizes were recorded, and flowering plants were tallied. Numbers of flowers and fruits were counted for a randomly chosen sub-sample of flowering plants in each plot. Apparent damage to plants was noted. Numbers of plants per hectare were calculated from the counts, size class distributions were constructed, and percentages of plants flowering and bearing fruits were calculated for each population. Threats to plants were summarized for each location. 


\section{Reproductive biology}

Observations of flowering and fruiting were recorded during field surveys. Controlled crosses were conducted at Santa Barbara Botanic Garden for ten taxa to determine degree of self-compatibility and flower, fruit, and seed productivity. Effects of hand-pollination treatments were tested using analysis of variance procedures.

\section{Data archival}

All field notes, maps and raw data sheets from this study are archived at the Channel Islands Field Station, California Science Center, USGS-BRD in Ventura, California. Duplicate copies are at the Santa Barbara Botanic Garden in Santa Barbara, California. Field observation forms for rare plants listed by the California Native Plant Society's Natural Diversity Database were sent to the CNDDB office in Sacramento, California. Channel Islands National Park is managing the rare plants database (Microsoft Access files and associated geographic information systems locations in ArcInfo.) 
Table 1. California Channel Islands rare plant taxa studied 1995-1996, under NBS Species at Risk program.

\begin{tabular}{|c|c|c|c|}
\hline Taxon & $\begin{array}{l}\text { Federal } \\
\text { status }\end{array}$ & $\begin{array}{l}\text { Distri- } \\
\text { bution }\end{array}$ & Field data collected this study \\
\hline $\begin{array}{l}\text { Arctostaphylos } \\
\text { confertiflora }\end{array}$ & PE & $\mathbf{R}$ & $\begin{array}{l}\text { - Ground surveys with field motes on habitat and } \\
\text { population condition, March 1994-August 1996, Santa } \\
\text { Rosa Island. All known locations visited, 75\% } \\
\text { potential habitat covered. }\end{array}$ \\
\hline Atriplex pacifica & $\mathrm{C} 2$ & $\begin{array}{l}\mathrm{A}, \mathrm{Cr} \\
\mathrm{R}, \mathrm{N}, \mathrm{B} \\
\mathrm{Ca}, \mathrm{Cl} \\
+\end{array}$ & $\begin{array}{l}\text { - Ground surveys with field notes on habitat and } \\
\text { population condition, October 1995-August 1996, Santa } \\
\text { Cruz Island. All but one known locations visited, 100\% } \\
\text { of potential habitat covered on Santa R osa Island and } \\
50 \% \text { covered on Santa Cruz Island. } \\
\text { Flower production data, June 1996, Santa Cruz Island. }\end{array}$ \\
\hline Castilleja mollis & PE & $\mathbf{R}$ & $\begin{array}{l}\text { - Ground surveys with field motes on habitat and } \\
\text { population condition, March 1994-August 1996, Santa } \\
\text { Rosa Island. All known locations visited, } 100 \% \\
\text { potential habitat covered. } \\
\text { - Census plot data, July 1994, Santa Rosa Is land. } \\
\text { - Demography data, July-August 1995, July-September, } \\
\text { 1996, Santa Rosa Island. } \\
\text { - Flower/inforescence production data, July-August 1995, } \\
\text { July-September 1996, Santa R osa Island. }\end{array}$ \\
\hline $\begin{array}{l}\text { Dendromecon rigida ssp. } \\
\text { harfordii }\end{array}$ & $\mathrm{C} 2$ & $\mathrm{Cr}, \mathrm{R}$ & $\begin{array}{l}\text { - Ground surveys with field motes on habitat and pop- } \\
\text { ulation condition, October 1995-August 1996, Santa } \\
\text { Rosa and Santa Cruz islands. All known Santa Rosa } \\
\text { locations visited, all but } 3 \text { known Santa Cruz locations } \\
\text { visited, } 75 \% \text { potential habitat covered, both islands. } \\
\text { - Flowe/fruit data, January-July 1996, Santa Cruz Island; } \\
\text { self-compatibility test rosses made 1996, SBBG. }\end{array}$ \\
\hline Dudleya candelabrum & $\mathrm{C} 2$ & $\mathrm{Cr}, \mathrm{R}$ & $\begin{array}{l}\text { - Ground surveys with field mtes on habitat and } \\
\text { population oondition, October 1995-August 1996, Santa } \\
\text { Rosa and Santa Cruz islands. All known populations } \\
\text { searched, 75\% potential habitat covered, both islands. } \\
\text { - Seed set data fom Santa Cruz populations and self } \\
\text { compatibility ests done at SBBG, spring-summer } 1996 \text {. } \\
\text { One Santa Rosa population completely censused into } \\
\text { size-class, reproductive stage, and damage categories, } \\
\text { fall } 1996 \text {. }\end{array}$ \\
\hline $\begin{array}{l}\text { Eriogonum grande var. } \\
\text { rubescens }\end{array}$ & $\mathrm{C} 2$ & $\begin{array}{l}\mathrm{A}, \mathrm{Cr} \\
\mathrm{R}, \mathrm{M}\end{array}$ & $\begin{array}{l}\text { Ground surveys with field motes on habitat and pop- } \\
\text { ulation condition, October 1995-August 1996, Santa } \\
\text { Rosa and Santa Cruz islands. All known populations } \\
\text { searched, 75\% potential habitat covered, both islands. } \\
\text { - Seed set data fom Santa Cruz and Santa Rosa, and self- } \\
\text { compatibility ests done at SBBG spring-summer } 1996 \text {. }\end{array}$ \\
\hline Erysimum ammophilum & $\mathrm{C} 2$ & $\mathrm{R},+$ & $\begin{array}{l}\text { Ground surveys with field mtes on habitat and } \\
\text { population condition, March 1994-August 1996, Santa } \\
\text { Rosa Island. All known locations visited, } 100 \% \\
\text { potential habitat covered. }\end{array}$ \\
\hline
\end{tabular}




\begin{tabular}{|c|c|c|c|}
\hline Taxon & $\begin{array}{l}\text { Federal } \\
\text { status }\end{array}$ & $\begin{array}{l}\text { Distri- } \\
\text { bution }\end{array}$ & Field data collected this study \\
\hline $\begin{array}{l}\text { Erysimum insulare ssp. } \\
\text { insulare }\end{array}$ & $\mathrm{C} 2$ & $\begin{array}{l}\mathrm{A}, \mathrm{Cr} \\
\mathrm{R}, \mathrm{M}\end{array}$ & $\begin{array}{l}\text { - Ground surveys with field mtes on habitat and } \\
\text { population condition, March 1994-March 1995, Santa } \\
\text { Rosa Island. All known bcations visited, 100\% } \\
\text { potential habitat covered on Santa Rosa Island and } \\
80 \% \text { on Santa Cnuz Island. } \\
\text { - Census plot data, May 1996, Santa Rosa Bland. }\end{array}$ \\
\hline Helianthumum greenei & PE & $\begin{array}{l}\mathrm{Cr}, \mathrm{R} \\
\mathrm{M}, \mathrm{Ca}\end{array}$ & $\begin{array}{l}\text { - Ground surveys with field mtes on habitat and } \\
\text { population condition, October 1995-August 1996, Santa } \\
\text { Rosa and Santa Cruz islands. All known populations } \\
\text { visited, 100\% potential habitat covered on Santa Rosa } \\
\text { Island and } 75 \% \text { on Santa Cruz Island. }\end{array}$ \\
\hline Heuchera maxima & PE & $\mathrm{A}, \mathrm{Cr}, \mathrm{R}$ & $\begin{array}{l}\text { - Ground surveys with field motes on habitat and } \\
\text { population condition, October 1995-August 1996, Santa } \\
\text { Rosa and Santa Cruz islands. All known populations } \\
\text { visited, } 75 \% \text { potential habitat covered, both islands. }\end{array}$ \\
\hline Jepsonia malvifolia & $\mathrm{C} 2$ & $\begin{array}{l}\mathrm{Cr}, \mathrm{R} \\
\mathrm{N}, \mathrm{Ca} \\
\mathrm{Cl}, \mathrm{G}\end{array}$ & $\begin{array}{l}\text { - Ground surveys with field mtes on habitat and } \\
\text { population condition, October 1995-August 1996, Santa } \\
\text { Rosa and Santa Cruz islands. All known populations } \\
\text { visited, } 100 \% \text { potential habitat covered on Santa Rosa } \\
\text { Island and } 75 \% \text { on Santa Cruz Island. } \\
\text { - Census plot data, February 1996, Santa Rosa and Santa } \\
\text { Cruz is lands. } \\
\text { Demography data, November 1995-February 1996, } \\
\text { Santa Rosa and Santa Cruz islands. }\end{array}$ \\
\hline $\begin{array}{l}\text { Lasthenia glabratassp. } \\
\text { coulteri }\end{array}$ & $\mathrm{C} 2$ & $\mathrm{R},+*$ & $\begin{array}{l}\text { - Ground surveys with field motes on habitat and } \\
\text { population condition, May-June 1995; March 1996, } \\
\text { Santa Rosa Island. Al known populations visited, 100\% } \\
\text { potential habitat covered. } \\
\text { - Census plot data, March 1996, Santa Rosa Island. }\end{array}$ \\
\hline $\begin{array}{l}\text { Lilium humboldtii ssp. } \\
\text { ocellatum }\end{array}$ & $\mathrm{C} 2$ & $\begin{array}{l}\text { A, Cr, R } \\
+\end{array}$ & $\begin{array}{l}\text { - Ground surveys with field mtes on habitat and } \\
\text { population condition, October 1995-August } 1996 \text {, Santa } \\
\text { Rosa and Santa Cruz islands. Al known populations } \\
\text { visited, } 75 \% \text { potential habitat covered, both islands. }\end{array}$ \\
\hline $\begin{array}{l}\text { Orobanche parishii ssp. } \\
\text { brachyloba }\end{array}$ & $\mathrm{Cl}$ & $\begin{array}{l}\mathrm{Cr}, \mathrm{R} \\
\mathrm{M}, \mathrm{Ca} \\
\mathrm{N},+,\end{array}$ & $\begin{array}{l}\text { - Ground surveys with field mtes on habitat and } \\
\text { population condition, March 1994-August 1996, Santa } \\
\text { Rosa and Santa Cruz islands. All known populations } \\
\text { visited, } 100 \% \text { potential habitat covered, both islands. } \\
\text { - Census plot data, September 1995, Santa Rosa Island. }\end{array}$ \\
\hline
\end{tabular}




\section{Federal Status:}

$\mathrm{C} 1$ and C2: These categories were recently eliminated by USFWS, but they are retained here to designate a degree of concern about the species.

C1 (Category 1) = Formerly applied to taxa for which USFWS had substantial information on biological vulnerability and threats to support the appropriateness of proposing to list the taxa.

C2 (Category 2) = Formerly applied to taxa for which USFWS had some information to possibly justify listing, but not enough information to immediately pursue listing the taxa.

$\mathrm{PE}=$ Proposed Endangered

Distribution:

Northern islands: A=A nacapa, , $\mathrm{Cr}=\mathrm{Santa} \mathrm{Cruz}, \mathrm{R}=$ Santa Rosa, $\mathrm{M}=\mathrm{San}$ Migue

Southern islands: $\mathrm{B}=$ Santa Barbara, $\mathrm{N}=\mathrm{San}$ Nicolas, $\mathrm{Ca}=$ Santa Catalina, $\mathrm{Cl}=\mathrm{San}$ Clemente, $\mathrm{G}=\mathrm{Guadalupe}$

$+=$ mainland

* indicates either possible extirpation or severely reduced numbers based on comparison of recent observations with herbarium specimens or literature.

SBBG = Santa Barbara Botanic Garden 


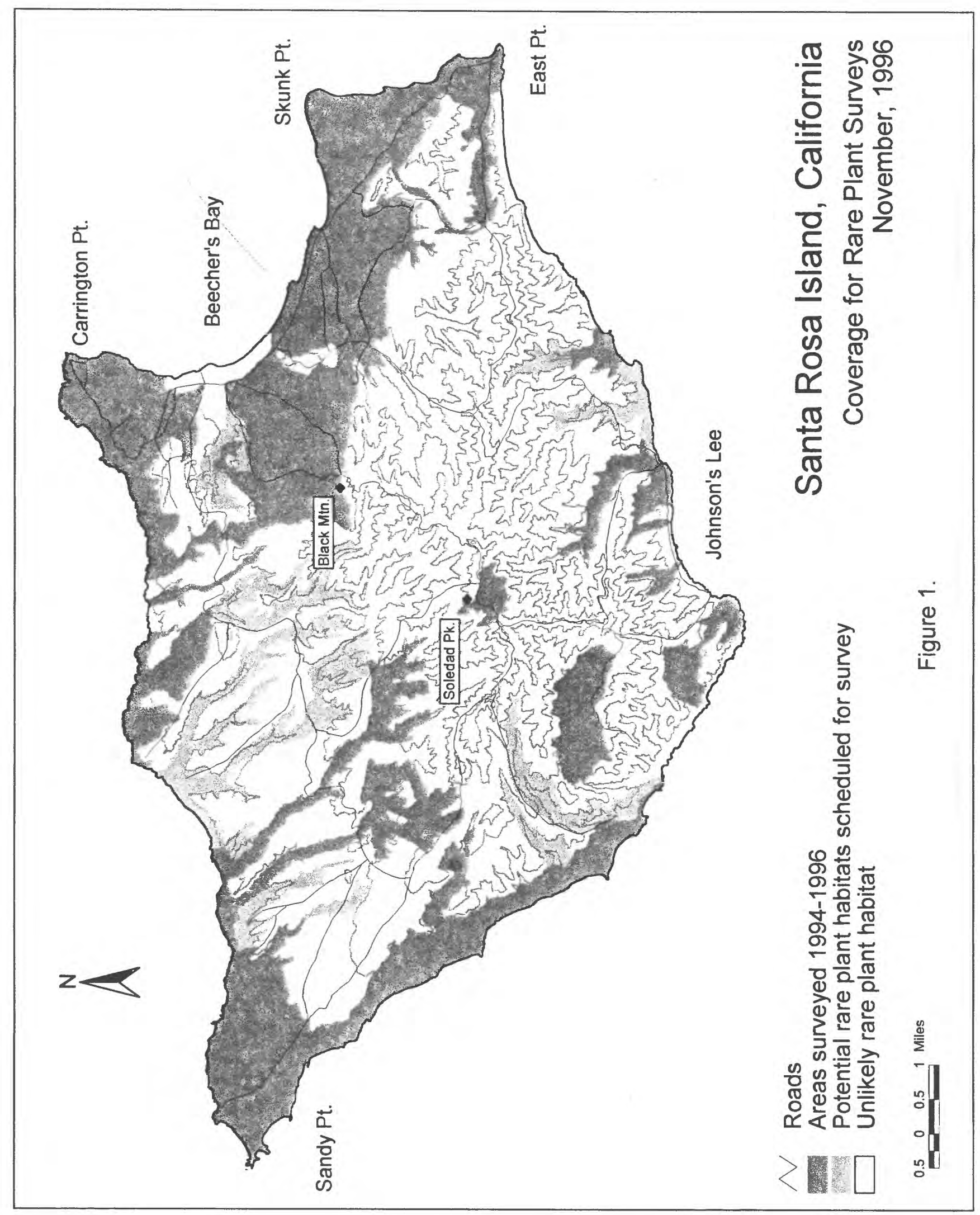




\section{RESULTS AND DISCUSSION}

\section{Arctostaphylos confertiflora Eastwood (Santa Rosa Island manzanita), Ericaceae}

Arctostaphylos confertiflora, a decumbent to erect shrub, is restricted to Santa Rosa Island (McMinn 1964; Munz and Keck 1963; Munz 1974; Wells 1993). Its ecolog-ical distribution has been described as sandstone outcrops (Wells 1993). A. tomentosa ssp. insulicola also occurs on Santa Rosa in similar habitats, and the two taxa are difficult to distinguish from one another in the field. Therefore, it is possible that some of the historic and current unvouchered $A$. confertiflora reports include individuals of A. tomentosa. Steve Junak (pers. comm.), Herbarium Curator, Santa Barbara Botanic Garden, believes that most of the manzanitas on Santa Rosa are A. confertiflora. Therefore, for survey purposes, when there was doubt, the plants were called $A$. confertiflora.

\section{Ground surveys}

Arctostaphylos confertiflora was first collected on Santa Rosa Island in 1927, and has since been documented in six of the island's canyons. We relocated it in all six canyons and found it in two additional, previously undocumented canyons. Its most common growth form is a low-growing shrub; less than $5 \%$ of the plants mapped in our survey were erect. All plants were growing on steep canyon walls, along rim rock, or in chaparral mixed with decumbent forms of Adenostoma fasciculatum and Quercus pacifica, generally on eroded bedrock. More than $90 \%$ of the plants seen were accessible to ungulates, and were browsed at the growing tips and pruned into multibranched or mushroomed forms. The areas under the canopies of the few large, erect Arctostaphylos confertiflora found were heavily trampled by elk and deer, and the bedrock was eroding away around the roots.

Arctostaphylos confertiflora plants were counted whenever they were encountered in the surveys. Plants were either scattered singly along nearly vertical canyon walls, or they were clustered in areas of about one hectare or less within chaparral. Eight such clusters were seen, ranging in size from 4 to 150 individuals each, with a median number of 50 plants per cluster.

\section{Reproductive Biology.}

Plants of $A$. confertiflora range from 0.1 to $1 \mathrm{~m}$ tall (Wells 1993). Flowers are bisexual, with 10 stamens, one pistil, and a radial, urn-shaped corolla composed of five fused petals. Few plants documented in this survey had flowers or fruits, and no seedlings or saplings were seen. 


\section{Atriplex pacifica A.Nelson (south coast saltbush or saltscale), Chenopodiaceae}

Atriplex pacifica, a monoecious annual, occurs on the mainland coast from Los Angeles County south to northern Baja California, and on all California Channel Islands except for San Miguel (Hall and Clements 1923; Munz and Keck 1963; Munz 1974; Taylor and Wilken 1993; Junak et al. 1995). Its ecological distribution has been described as sandy soils of coastal bluffs, in association with coastal shrubland or coastal strand communities (Hall and Clements, 1923; Munz 1974; Taylor and Wilken 1993; Junak et al. 1995).

\section{Ground surveys.}

The immediate coastline of Santa Cruz and Santa Rosa islands remains the least accessible area for botanical surveys because of steep slopes without beaches and the general lack of roads and trails, especially on Santa Cruz Island. This inaccessibility constrained a complete search for populations of Atriplex pacifica. However, both of the two known populations on Santa Cruz Island were visited; the only known Santa Rosa Island site at the mouth of Trancion (Tranquillon) Canyon was inaccessible from land and was not visited.

We counted 28 and 36 plants (mean $=32 \pm 4)$ at Valley Anchorage and Coches Prietos Anchorage, respectively. Both populations occurred on exposed ( $<30 \%$ cover), coastal sites at elevations between 30 and $60 \mathrm{~m}$ on friable soils derived from decomposing metamorphic (Valley Anchorage) or volcaniclastic (Coches Prietos Anchorage) rocks. Common associates include Artemisia californica, Coreopsis gigantea, Dudleya greenei, Hazardia detonsa, Isocoma menziesii, Rhus integrifolia, Opuntia littoralis, and Opuntia prolifera. These taxa are characteristic of insular coastal-sage shrublands (Philbrick and Haller 1977; Westman 1983). Both sites were characterized by $20 \%$ to $30 \%$ vegetative cover.

Reproductive Biology.

Plants of Atriplex pacifica are typically prostrate, with many-branched stems radiating from a central stem. Atriplex pacifica is monoecious, producing clusters of 2 to 3 proximal pistillate flowers and numerous staminate flowers on short axillary branches at each node of the branching plant. Each pistillate flower is enclosed by two fused bracts. The entire unit is deciduous at maturity and serves as a dispersal unit. General studies of the breeding system were not conducted. However, related species are self-compatible; in such species pollination is apparently effected by a combination of selfing and wind-pollination (Proctor et al. 1996).

Pistillate flower (hence potential fruit) production at Coches Prietos Anchorage was quantified from estimates of plant area and number of pistillate flowers in June 1996. The large number of flowering nodes and pistillate flowers precluded complete counts for each plant. Because most plants were generally circular in outline and composed of prostrate stems, plant size was estimated by horizontal plant area, calculated using ( $\mathrm{r} 1)(\mathrm{r} 2)$. One radius $(\mathrm{r} 1)$ was represented by the longest axis of the plant, measured horizontally from the central stem to growing tip. The second radius (r2) was arbitrarily calculated by halving the horizontal plant axis width that was perpendicular to the longest axis. The number of pistillate flowers was estimated from three $400 \mathrm{~mm}^{2}(20 \times 20 \mathrm{~mm})$ quadrats placed along the longest axis of each plant. 
Every other plant (18 plants) was censused. Estimated mean $( \pm \mathrm{SE})$ plant diameter was $182 \mathrm{~mm} \pm 14$; estimated mean plant area was $28,742 \mathrm{~mm}^{2} \pm 3,940$; estimated mean number of pistillate flowers per $400 \mathrm{~mm}^{2}$ was $11.8 \pm 1.3$. The mean number of pistillate flowers per plant $(845 \pm 115)$ was calculated from mean flower per $\mathrm{mm}^{2}$ and mean area. Because fruiting maturity occurs in late summer (August-Sep-tember), we were unable to estimate the number and viability of fruits. However, potential fruit production at Coches Prietos does not appear limited by number of pistillate flowers.

Both sites are subject to natural erosion, which is slightly exacerbated by evident trails used by pigs. However, no evidence of excavation or browsing by pigs or herbivory by other animals was observed. The location of both sites near popular sailing anchorages and areas of occasional recreational use apparently pose the only potential damage to plants, which may be considered minimal.

\section{Castilleja mollis (Pennell) (soft-leaved Indian paintbrush), Scrophulariaceae}

Castilleja mollis was thought to be distributed along the mainland coast in San Luis Obispo County and on Santa Rosa Island (Hoover 1970, Munz and Keck 1973). However, it is now recognized as a taxon restricted to Santa Rosa Island (Heckard et al. 1991, Ingram 1990). It is a hemi-parasitic, prostrate subshrub of coastal dunes and sandy coastal bluffs, associated with coastal scrub species such as Isocoma menziesii, Erigeron glaucus, Distichlis spicata, Atriplex californica, and Astragalus miguelensis. Host plant relationships are unknown, and it is possible that several taxa serve as hosts (Margriet Wetherwax, Jepson Herbarium, UC Berkeley, pers. comm.).

\section{Ground surveys.}

Castilleja mollis was noted from five areas of Santa Rosa Island, in surveys and collections dating from the 1930's. We were able to relocate two populations. We searched appropriate habitats at the three remaining three localities in 1994 and 1995 , but failed to find any $C$. mollis plants, or $C$. affinis that could have been mistaken for $C$. mollis in the past. A very large C. mollis population occurs intermittently along ca. $4 \mathrm{~km}$ of the northwestern shore between Jaw Gulch and Sandy Point. More than 1,000 individuals occur there in sandy openings or on thin sandy soils over limestone terrace deposits in scat-tered groups of ten to several hundred individuals. Several hundred plants exist on the north- and northwest-facing bluffs of Carrington Point, in narrow bands where vegetation has less than about $60 \%$ cover and trailing disturbance from cattle, deer, and elk is minimal. This population apparently hybridizes with $C$. affinis, which is most common on the uppermost slopes of the bluff. Both the Jaw Gulch-Sandy Point and Carrington Point populations have been disturbed by deer and elk hoof scraping in the past (Sarah Chaney, Channel Islands National Park, pers. comm.), and this activity was especially apparent in our surveys in the fall of 1996.

\section{Population census}

Castilleja mollis density was sampled during 1994 ground surveys at both the Carrington Point and Jaw Gulch populations. Twelve $25 \times 4$ meter belt transects were randomly located within population boundaries at low and high elevations. Six transects were sampled at Carrington Point and seven at Jaw Gulch/Sandy Point. All Castilleja mollis plants rooted in the belt transect were counted. Number of broken stems was counted on five randomly chosen plants in each plot. A total of 1,002 plants were counted 
in the twelve plots, for an overall mean of $0.84 \pm 0.66$ plants $/ \mathrm{m}^{2}$. The mean number of plants on Carrington Point was $0.51 \pm 0.38$ plants $/ \mathrm{m}^{2}$, and $1.16 \pm 0.75 \mathrm{plants} / \mathrm{m}^{2}$ at Jaw Gulch. Broken stems ranged from $28 \%$ to $71 \%$ of stems tallied, with an overall mean of $51 \%$. Broken stems on Carnington Point averaged 55\%, versus $44 \%$ in the Jaw Gulch population.

Permanent demography plots $(5 \times 5 \mathrm{~m})$ were installed June-August 1995, within both populations: six at Carrington Point (three coastal bluff sites, each with a high and low elevation plot) and three in the nearly level marine terraces between Jaw Guch and Sandy Point. All plants within plots were mapped and tagged. Inflorescences and numbers of broken stems were counted. Each plot was re-sampled June-early September 1996. The same measurements were made again, and mortality and new plants were recorded.

Tables 2 and 3 summarize flowering, damage, and mortality data for Castilleja mollis demography plots sampled in 1995 and 1996, respectively. In 1995, 234 plants were tagged in plots at both sites, for a mean density of $1.04 \pm 0.58 \mathrm{plants} / \mathrm{m}^{2}$. A total of 199 plants was present in plots in 1996 , with a mean density of $0.88 \pm 0.65 / \mathrm{m}^{2}$. In 1995 , plants with flowers ranged from $51.4 \%$ to $83.3 \%$ of all plants tagged. Between $6.2 \%$ and $57.1 \%$ of plants had stems broken by trampling. In 1996 , flowering plants ranged from 0 to $84.2 \%$ of plants in plots at Carrington Point, and from $2.8 \%$ to $15.7 \%$ at Jaw Gulch. Plants with broken stems ranged from $47.1 \%$ to $93.8 \%$ on Carrington Point, and from $23.5 \%$ to $36.7 \%$ at Jaw Gulch. 
Table 2. Numbers of plants, flowering, and damage in Castilleja mollis plots sampled June-July 1995, Santa Rosa Island.

\begin{tabular}{||c|c|c|c||}
\hline Location & Number of plants & \% flowering & \% with broken stems \\
\hline Carrington Point & 12 & 66.7 & 50.0 \\
Plot 1 & 48 & 81.2 & 29.2 \\
Plot 2 & 18 & 83.3 & 11.1 \\
Plot 3 & 11 & 72.7 & 18.2 \\
Plot 4 & 16 & 87.5 & 6.2 \\
Plot 5 & 17 & 64.7 & 11.8 \\
Plot 6 & 30 & 70.0 & 16.7 \\
Jaw Gulch & 47 & 59.6 & 12.8 \\
Plot 7 & 35 & 51.4 & 57.1 \\
Plot 8 & & & \\
Plot 9 & &
\end{tabular}

Table 3. Numbers of plants, flowering, damage and mortality data for Castilleja mollis plots sampled June-September 1996, Santa Rosa Island.

\begin{tabular}{||l|c|c|c|c|c|c||}
\hline $\begin{array}{c}\text { Location \& } \\
\text { plot \# }\end{array}$ & $\begin{array}{c}\text { Number of } \\
\text { plants in } \\
\text { plots }\end{array}$ & $\begin{array}{c}\text { \% Plants } \\
\text { flowering }\end{array}$ & $\begin{array}{c}\text { \% Plants } \\
\text { with } \\
\text { broken } \\
\text { stems }\end{array}$ & $\begin{array}{c}\text { \% Plants } \\
\text { dead for no } \\
\text { apparent } \\
\text { reason }\end{array}$ & $\begin{array}{c}\text { \% Plants } \\
\text { destroyed } \\
\text { by } \\
\text { deer/elk } \\
\text { scraping }\end{array}$ & $\begin{array}{c}\text { Number } \\
\text { of new } \\
\text { plants in } \\
1996^{2}\end{array}$ \\
\hline Carrington Point & 16 & 52.9 & 47.1 & 8.3 & 0 & 5 \\
Plot 1 & 62 & 52.2 & 71.6 & 10.4 & 0 & 19 \\
Plot 2 & 16 & 84.2 & 47.4 & 16.7 & 0 & 1 \\
Plot 3 & 14 & 33.3 & 60.0 & 9.1 & 0 & 4 \\
Plot 4 & 15 & 50.0 & 93.8 & 6.2 & 0 & 0 \\
Plot 5 & 12 & 0 & 47.4 & 29.4 & 17.6 & 3 \\
Plot 6 & 13 & 6.7 & 36.7 & 10.0 & 46.7 & 0 \\
Jaw Gulch & 34 & 15.7 & 23.5 & 21.3 & 12.8 & 3 \\
Plot 7 & 17 & 2.8 & 27.8 & 11.4 & 45.7 & 1 \\
Plot 8 & & & & & \\
Plot 9 &
\end{tabular}

${ }^{1}$ Plots on Carrington Point were hoof scraped by deer, while Jaw Gulch plots were hoof scraped by elk.

${ }^{2}$ None of these plants appeared to be seedlings. 
Plot 6, at Carrington Point, and all Jaw Gulch plots were sampled in early September, 1996 (plots 1-5 at Carrington were sampled July-August, 1996). Signs of fresh hoof scraping of the ground surface were common at all of the plots sampled in September, whereas scraping was not commonly observed in July-August. Eighteen percent of the tagged plants in plot 6 at Carrington Point plot had been uprooted and killed by scraping, while 13 to $48 \%$ (mean $=35.1 \pm 19.3$ ) of tagged plants in the three Jaw Gulch plots were killed (Table 3). Patches of ground ranging from one-half to about $2 \mathrm{~m}^{2}$ in area were scraped clear of vegetation to a depth of 1 to $12 \mathrm{~cm}$. This disturbance was distributed through-out the $C$. mollis habitat at both locations, and $C$. mollis individuals, as well as other taxa, were broken, uprooted, and killed by the activity. Deer scat was associated with the disturbance on Carrington Point, while elk scat was associated with disturbance at Jaw Gulch. This disturbance was not seen earlier in the season, neither during spring (March-May) surveys nor summer (JuneAugust) sampling periods. We revisited all of the Carrington plots in late September to quantify damage in all six plots. Fresh scrapes were present in four of the six plots, but no tagged Castilleja mollis plants were affected by this new scraping. We could not revisit Jaw Gulch plots because the Santa Rosa Island annual elk hunt limited access to these sites.

Ungulate trails are apparent on the upper one-third of Carrington Point slopes supporting $C$. mollis, and deer scat is scattered throughout the population area from upper to lower slopes. Fresh cow, deer, and elk droppings were present in the Jaw Gulch population in 1994 to 1996, and cow and elk trails are apparent throughout the $C$. mollis population from Jaw Gulch to Sandy Point. Several times during our fieldwork, cattle, deer, and elk came through the $C$. mollis populations we were sampling. They traveled both on established trails and off trails. Given such behavior, it is likely that the broken stems we documented in plots were from ungulate trampling.

\section{Reproductive Biology}

Castilleja mollis flowers are bisexual and zygomorphic. Our surveys indicate that they flower nearly continuously, with a flowering peak occurring in the spring months. They appear to be visited by a variety of flies and bees, and some flowers in our study plots appeared to be preyed upon by one or several types of insects.

\section{Dendromecon rigida Benth. ssp. harfordit (Kellogg) Raven [synonym: Dendromecon harfordii Kellogg ssp. harfordiil. (northern island bush poppy or channel island tree poppy). Papaveraceae}

Dendromecon rigida ssp. harfordii is a shrub restricted to Santa Rosa and Santa Cruz islands (McMinn 1964; Munz and Keck 1963; Munz 1974; Junak et al. 1995). Its ecological distribution has been described as occurring on rocky slopes, canyons, and exposed ridge tops, in association with chaparral or pine-forest communities (Munz 1974; Clark 1993; Junak et al. 1995).

Seeds of the mainland Dendromecon rigida ssp. rigida are dispersed by ants (Berg 1966; Bullock 1974). Germination of D. rigida ssp. rigida seeds are enhanced after scarification or treatment by fire (Neal 1974). Seeds of ssp. harfordii from Santa Cruz Island showed significantly enhanced germination with both heat and fire treatments as compared to untreated seeds (M. Carroll, Santa Barbara Botanic Garden, 
pers. comm.). These studies suggest that recruitment and establishment of Dendromecon populations depend on dispersal by ants and fire.

Ground surveys.

Dendromecon rigida ssp. harfordii was known from two sites on Santa Rosa Island, dating from 1975 and 1982 . We found 3 and 5 plants at these sites, respectively; and two new occurrences of one plant each were found in previously undocumented locations. Collections were also made from Santa Rosa in 1927, but no location information was given in the associated field notes, so it was impossible to determine their localities. Searches of other potential habitats failed to find more individuals on Santa Rosa, and no seedlings were seen. Most of the 10 plants were growing on canyon walls of sandstone bedrock, between 150-215 m elevation. Plants were in exposed locations high on the canyon walls where vegetation cover was generally less than $50 \%$. They were multi-branched individuals 0.5 to $2.0 \mathrm{~m}$ in height. Fruits and flowers were present on all but one of the plants. Common associates include Quercus pacifica, Heteromeles arbutifolia, Arctostaphylos tomentosa, Baccharis pilularis, Rhus integrifolia, Salvia brandegei, Mimulus flemingii, and Adenostoma fasciculata. These species are characteristic of the transition zone between Santa Rosa island woodland and coastal sage scrub. Two of the four sites were criss-crossed with ungulate trails, and roots of Dendromecon and associated plants were exposed by erosion.

Santa Cruz Island $D$. rigida ssp. Harfordii collections date from 1893 , and at least 10 sites were documented prior to 1995 . Seven of the 10 known sites were accessible from land. We located an additional 3 populations in suitable sites not previously searched. Population size for all 12 occurrences ranged from 1 to 53 (mean $=19 \pm 5$, median $=12$ ). Most populations generally occurred on steep slopes at elevations ranging between 30 and $420 \mathrm{~m}$. Seventy-five percent of the populations occurred on south-facing or west-facing slopes that are characterized by high levels of insolation. Typical substrates are thin, rocky soils derived from either metamorphic or volcanic rocks. Most plants were 1 or more meters tall. Some plants shorter than $1 \mathrm{~m}$ showed evidence of connections to adjacent, larger plants by means of rhizomes. No seedlings were observed in any population.

The most common Santa Cruz island associates include Arctostaphylos insularis, Ceanothus megacarpus ssp. insularis, Heteromeles arbutifolia, Prunus ilicifolia ssp. lyonii, and Quercus pacifica. Cercocarpus betuloides, Rhamnus pirifolia, Rhus ovata, Arctostaphylos tomentosa, and Ceanothus arboreus were also found at each of one or two of the sites. These taxa are characteristic of Santa Cruz insular chaparral (Philbrick and Haller 1977; Bjorndalen 1978; Minnich 1980). A majority of the populations were associated with mature, well-developed chaparral. Five of the 12 sites were characterized by vegetative cover between $80 \%$ and $100 \%$, and two other sites were characterized by $50 \%$ to $80 \%$ cover. The remaining five populations occurred on sites with less than $20 \%$ cover.

Reproductive Biology.

Plants of Dendromecon rigida ssp. harfordii are erect shrubs, ranging from 1 to 2 $\mathrm{m}$ tall. Flowers are bisexual and biradial, with 4 large, yellow petals, many stamens, and 1 pistil. General observations during the course of the survey indicate that the flowers are visited by a range of nectar- and pollen-collecting insects, including small beetles, flies, bees, and wasps. 
Flower and fruit production were estimated between January and July 1996 at four different sites (Centinela, Stanton, Upper Islay, and Lower Islay) on Santa Cruz Island. Ten plants at each site were tagged and visited at two-month intervals (January, March, May, and July). The total number of flowers and fruits was counted on each plant; all fruits greater than $6 \mathrm{~cm}$ long were removed. Thus, the fruits observed at subsequent sampling dates were considered to have been produced during the previous two-month period. The number of seeds per fruit was estimated from a random sample of 20 fruits each in January and July in two populations, Lower Islay and Stanton.

The number of flowers per plant ranged from 0 to 15 over the six-month period. No significant differences in mean number of flowers were found among sites during any of the four sampling periods (ANOVA, $p=0.213$ in January to $p=0.724$ in July, $d f$ $=3,36$ ). However, significant differences were found among sampling periods with combined data (ANOVA, $\mathrm{p}=0.001$, among $\mathrm{ms}=18.8$, within $\mathrm{ms}=0.7$, $\mathrm{df}=3,156$ ). The number of flowers per plant ( $n=40,10$ per site) were: $1.8 \pm 0.2$ in January, $2.9 \pm$ 0.1 in March, $6.9 \pm 0.1$ in May, and 7.6 \pm 0.1 in July. The mean number of fruits per plant ranged from 0 to 14 over the six month period. No significant differences in mean number of fruits were found among sites during any of the four sampling periods (ANOVA, $p=0.131$ in May to $p=0.982$ in January, $d f=3,36$ ). However, mean fruit number was significantly greater in July than in January, March, and May (ANOVA, p $=0.001$, among $\mathrm{ms}=14.3$, within $\mathrm{ms}=0.6, \mathrm{df}=3,156)$. The number of fruits per plant per month $(n=40)$ were: $2.3 \pm 0.1$ in January, $2.2 \pm 0.1$ in March, $3.8 \pm 0.1$ in May, and $7.6 \pm 0.1$ in July. The number of seeds per fruit ranged from 1 to 10 . Significant differences were found among sampling periods (ANOVA, $\mathrm{p}=0.005$, among $\mathrm{ms}=1.5$, within $\mathrm{ms}=0.3 \mathrm{df}=3,76$ ). The mean number of seeds per fruit in January were $4.9 \pm$ 0.1 at both Islay and Stanton, but were 7.0 \pm 0.1 at Islay and 7.3 \pm 0.1 at Stanton in July.

Self-compatibility was estimated from controlled crosses performed on three plants at the Santa Barbara Botanic Garden. Twenty flowers on each plant were handpollinated, using pollen from the same flower or flowers on the same plant. For studies of cross-compatibility, ten additional flowers were hand-pollinated on each plant, using pollen derived from separate plants. Pollinated flowers were bagged with nylon mesh to exclude insect visitation. No significant differences were seen among plants for selfpollinated seed set (ANOVA: $\mathrm{p}=0.77$, among $\mathrm{ms}=0.02$, within $\mathrm{ms}=0.06, \mathrm{df}=2,57$ ) or cross-pollinated seed set (ANOVA: $\mathrm{p}=0.55$, among $\mathrm{ms}=7.9$, within $\mathrm{ms}=10.7, \mathrm{df}=$ 2,27 ). The mean number of seeds per fruit in self-pollinated flowers was $0.1 \pm 0.1$; the number of seeds in out-crossed flowers was $4.8 \pm 1.0$.

These results suggest that Dendromecon rigida ssp. harfordii is selfincompatible. Consequently, fruit and seed production may depend on population size and the presence of insects actively foraging on flowers of the species. This was confirmed by observations of solitary plants on Santa Cruz Island. At one of two sites, no fruit production was observed over a six month period. 


\section{Dudleya candelabrum Rose (candleholder dudleya), Crassulaceae}

Dudleya candelabrum is a succulent, perennial herb with a distribution on Santa Rosa and Santa Cruz islands (Munz and Keck 1963; Munz 1974; Junak et al. 1995). Its ecological distribution has been described as rocky sites, often on north-facing slopes, of coastal bluffs, ridgetops, in association with coastal scrub, chaparral or pine-forest communities (Munz 1974; Bartel 1993; Junak et al. 1995).

\section{Ground surveys.}

Dudleya candelabrum was known from three locations on Santa Rosa Island prior to 1995 (records date from 1941, 1973 and 1990). One of these populations is on a north-facing bluff in the interior of the island; the other two are on marine terrace outcrops and coastal bluffs. All three sites were relocated in 1996 and population sizes were 5 , ca. 100 and 505 plants. Two new sites were found in Tecolote Canyon on the north side of the island, with 35 and 320 plants each. Older records do not give approximate population sizes, so we could not determine population trends. The largest three of the five occurrences were on sand or sedimentary rock bluff faces with less than $40 \%$ cover, in areas out of reach of ungulates. The most common associates included Isocoma menziesii and either Atriplex californica or Atriplex semibaccata. These taxa are characteristic of insular coastal bluff scrub (Philbrick and Haller 1977; Minnich 1980). The population with five individuals occurred on slightly sloping, sedimentary rock outcrops in annual grassland in a pasture used by cattle, horses, and deer. Searches of other potential habitats failed to locate more plants, although it is possible that some Santa Rosa Island Dudleya populations mapped as $D$. greenei are $D$. greenei $x$ D. candelabrum hybrids (Steve McCabe, Arboretum, UC Santa Cruz, pers. comm.).

We surveyed seven populations on Santa Cruz Island; all but one were new occur-rences for the island. Six older populations are known from 1930-1979 surveys, but none of these sites were accessible by land, and they were not visited in 1995-1996. Population size ranged from 31 to over 100 plants (mean $=52 \pm 23$, median $=50$ ). Most populations generally occurred on steep, rocky slopes or cliff faces at elevations ranging between 20 and $365 \mathrm{~m}$. All of the populations occurred on northeast- to northwestfacing slopes. Typical substrates are rocky soils or crevices derived from either metamorphic or volcanic rocks. No seedlings were observed in any population, but many non-flowering rosettes generally were in a smaller size class than those flowering, suggesting variation in age structure.

On Santa Cruz Island, about half of the populations were associated with species characteristic of chaparral (Philbrick and Haller 1977; Bjorndalen 1978), including Quercus pacifica, Adenostoma fasciculatum, Ceanothus arboreus, and Cercocarpus betuloides. The other half were associated with Artemisia californica and other taxa indicative of coastal scrub. Half of the sites were characterized by vegetative cover between $20 \%$ and $40 \%$; the others were characterized by $50 \%$ to $80 \%$ cover. However, most plants at sites with cover greater than $50 \%$ generally occurred in open microsites among shrubs. 


\section{Population census.}

Numbers of individuals present in the largest Santa Rosa Island D. candelabrum population were tallied in November, 1996. All individuals seen were tallied as either plants which had flowered in 1996 (flowering stem present) or which showed no evidence of recent flowering. Within these two categories, individuals were tallied as: 1) live, rooted; 2) live, uprooted; 3) dead, rooted; or 4) dead, uprooted. Within these categories, all individuals were tallied in three size classes defined in the field: small (less than $4 \mathrm{~cm}$ diameter), medium (4 to $10 \mathrm{~cm}$ diameter), and large (greater than $10 \mathrm{~cm}$ diameter). The diameter was considered to be that of either the caudex or the rosette, whichever was larger. Table 4 shows the census results. A total of 505 live individuals and 45 dead individuals were found. Of the live individuals, 212 (42\%) flowered in 1996 and $293(58 \%)$ were vegetative only.

Table 4. Results of Nov. 11, 1996 census of Dudleya candelabrum south of Skunk Point, Santa Rosa Island.

\begin{tabular}{||l|l|l|l|l|l|l||}
\hline & Flowered & & & $\begin{array}{l}\text { Did not } \\
\text { flower }\end{array}$ & & \\
\hline & Small & Medium & Large & Small & Medium & Large \\
\hline $\begin{array}{l}\text { Live, } \\
\text { rooted }\end{array}$ & 17 & 131 & 50 & 130 & 144 & 3 \\
\hline $\begin{array}{l}\text { Live, } \\
\text { uprooted }\end{array}$ & 3 & 11 & 0 & 14 & 2 & 0 \\
\hline $\begin{array}{l}\text { Dead, } \\
\text { rooted }\end{array}$ & 0 & 2 & 0 & 24 & 11 & 0 \\
\hline $\begin{array}{l}\text { Dead, } \\
\text { uprooted }\end{array}$ & 2 & 0 & 0 & 6 & 0 & 0 \\
\hline \hline
\end{tabular}




\section{Reproductive Biology.}

Plants of Dudleya candelabrum are composed of succulent, basal leaf rosettes that bear scapose inflorescences with many flowers. Flowers are bisexual and radial, with five petals, 10 stamens, and five separate pistils (Moran 1951; Munz and Keck 1963; Munz 1974; Bartel 1993). General observations during the course of the survey indicate that the flowers are visited by a range of small insects, including flies and bees.

Reproductive biology under natural conditions was assessed by estimating the number of seeds per flower in three populations on Santa Cruz Island (Black Point, Centinela, Stanton). Five flowers on each of 10 plants were sampled at fruiting. No significant differences were found among plants at each of the three sites (ANOVA: $\mathrm{p}=$ $0.5,0.8,0.7$, respectively, $\mathrm{df}=9,40$ ). An ANOVA of seeds per flower, combined by population, showed no significant differences among sites (ANOVA: $p=0.8$, among $\mathrm{ms}$ $=0.2$, within $\mathrm{ms}=1.2, \mathrm{df}=2,147)$. Mean seed set $( \pm \mathrm{SE})$ per flower per plant $(n=50)$ was $13.6 \pm 1.0$ at Black Point, $14.8 \pm 1.0$ at Centinela, and $14.3 \pm 1.1$ at Stanton.

Self-compatibility was estimated from controlled crosses performed on six plants at the Santa Barbara Botanic Garden. Self-compatibility was estimated by pollinating 10 flowers on each plant, using pollen from the same flower or flowers on the same plant. Flowers were bagged with nylon mesh to exclude insect visitation. To estimate the level of self-pollination, 10 flowers on each of four different plants were covered with nylon mesh to exclude pollinators, but were not hand-pollinated. The number of flowers was insufficient to estimate seed set in cross-pollinated flowers. No significant differences in seed set from self-pollinations were found (ANOVA: $p=0.12$, among ms $=0.95$, within $\mathrm{ms}=0.52, \mathrm{df}=5,54$ ). The mean number of seeds per flower in selfpollinated flowers was $15.9 \pm 0.6$. No significant differences in seed set from unmanipulated flowers were found (ANOVA: $\mathrm{p}=0.08$, among $\mathrm{ms}=1.29$, within $\mathrm{ms}=$ 0.53 , $\mathrm{df}=3,36$ ). The mean number of seeds per flower in unpollinated, bagged flowers was $0.8 \pm 0.3$.

These results show that although Dudleya candelabrum is self-compatible, insect visitation is required to ensure pollination and seed production. The number of seeds per fruit in manipulated self-pollinations (15.9) was only slightly higher than that found in natural populations (range $=13.6$ to 14.8 ), suggesting that natural pollination does not limit seed set in natural populations. 


\section{Eriogonum grande E.Greene var. rubescens (E.Greene) Munz (red buckwheat, red- flowered buckwheat), Polygonaceae}

Eriogonum grande var. rubescens is a suffrutescent, perennial herb with a distribution on Anacapa, Santa Cruz, Santa Rosa, and San Miguel islands (Munz and Keck 1963; Munz 1974; Junak et al. 1995). Its ecological distribution has been described as occurring on rocky soils of coastal bluffs and slopes, in association with coastal sage scrub and grassland communities (Munz 1974; Reveal 1989; Junak et al. 1995).

\section{Ground surveys.}

Eriogonum grande var. rubescens was collected sporadically from 1929 to 1979 , from seven locations on Santa Rosa Island. Plants were present in all of these locations 1995-1996, and an additional 15 populations were found in our surveys. The 22 populations surveyed ranged in size from one isolated plant to more than 1,000 individuals scattered over several hectares. Mean population size was $143 \pm 291$; the median was 30 plants.

Eriogonum grande var. rubescens populations occurred in two contrasting habitats on Santa Rosa. They ocurrred on the northern shores of the island as scattered bands of plants in open microsites along sandy marine terraces between 6 and $46 \mathrm{~m}$ elevation ( 5 of 22 occurrences, 50 to $1,000+$ plants per occurrence, mean $=280 \pm 407$, median $=100$ ). They also occurred as scattered individuals or clumps of individuals on canyon walls, growing in bare, eroded sandstone or in thin sandy soils over sandstone bedrock $(n=17$, mean $=106 \pm 240$, median $=30)$. The dune populations have a more compact and decumbent growth form than the canyon plants; there may be some genetic differentiation between these two types. Most populations on Santa Rosa Island had many plants with browsed inflorescences. Common associates on the marine terraces were characteristic of the coastal bluff and stabilized dune communities, including Isocoma menziesii, Abronia umbellata, Camissonia cheiranthifolia, Erigeron glaucus, Atriplex californica, Lasthenia californica, Malacothrix incana, Mesembryanthemum crystallinum, Poa douglasii, and Hordeum murinum. The most common canyon associates included Artemisia californica, Baccharis pilularis, Eriogonum arborescens, Rhus integrifolia, and Salvia brandegei. These taxa are characteristic of insular coastal scrub (Philbrick and Haller 1977; Minnich 1980). There were both flowering and vegetative plants in each of the 22 populations.

Eriogonum grande var. rubescens was known from six Santa Cruz locations prior to 1995 . One of these sites was revisited in 1996, and more than 200 plants were present there as three distinct, separate populations. An additional undocumented five populations were located in one of the island's western canyons. Population size ranged from 7 to over 200 plants (mean $=56 \pm 20$, median $=30$ ). 
Most populations on Santa Cruz Island occurred on sandy soils of bluffs at elevations between 15 and $60 \mathrm{~m}$. Most sites were located on west- to north-facing slopes, with cover ranging between $40 \%$ and $90 \%$ cover. No seedlings were observed in any population. However, most populations were composed of both reproductive and vegetative individuals. In general, most vegetative plants were smaller in stature and areal extent than reproductive plants.

On Santa Cruz Island, Eriogonum grande var. rubescens was the dominant species at most sites, although some common associates included Ambrosia chamissonis, Artemisia californica, and Isocoma menziesii. These species, including $E$. grande var. rubescens, are characteristic of coastal strand or coastal scrub communities (Philbrick and Haller 1977; Minnich 1980; Junak et al. 1995).

\section{Reproductive Biology.}

Plants of Eriogonum grande var. rubescens range from 0.5 to $1 \mathrm{~m}$ tall. Flowers are bisexual and radial, with six red tepals, nine stamens, and one pistil (Munz and Keck 1963; Munz 1974; Reveal 1989). Each pistil becomes an achene in fruit and encloses one seed. Inflorescences are composed of 20 to many flowers, sub-tended by an involucre. The number of involucres per plant ranges from 15 to several hundred. General observations during the course of the survey indicate that the flowers are visited by a range of nectar-collecting insects, including small flies and bees.

The assessment of reproductive biology under natural conditions was limited to estimates of seed set (i.e. equivalent to fruit) at three sites on Santa Cruz Island (Bluff, Christy Beach, Sauces) and at one Santa Rosa site (Jaw Gulch). Six plants at Jaw Gulch and ten plants at each site on Santa Cruz Island were randomly sampled for fruits. Ten inflorescences (i.e. involucres + flowers) on each plant were collected and combined into a single sample. Five separate subsamples of 100 flowers were randomly drawn from each plant sample and scored for the presence or absence of fruits. No significant differences were found among plants in any population (ANOVA: Santa Cruz Island, $p=0.6-0.9, \mathrm{df}=9,40$, Santa Rosa Island, $p=0.6, \mathrm{df}=5,18$ ). The number of fruits per sample of 100 flowers in each of the populations was: $5.7 \pm 1$ at Jaw Gulch $(n=30) ; 10.7 \pm 1$ at Bluff $(n=50), 7.8 \pm 1$ at Christy $(n=50)$, and $7.6 \pm 3$ at Sauces $(n=50)$.

Self-compatibility was estimated from controlled crosses performed on five plants at the Santa Barbara Botanic Garden. Self-compatibility was estimated by pollinating flowers on each plant, using pollen from the same flower or flowers on the same plant. Cross-compatibility was estimated by pollinating flowers on each plant, using pollen derived from separate plants. Flowers were bagged with nylon mesh to exclude insect visitation. To estimate the level of self-pollination, flowers on each of five plants were covered with nylon mesh to exclude pollinators, but were not handpollinated. For each treatment, all flowers in several involucres on each plant were pollinated. Flower clusters were bagged with nylon mesh to exclude insect visitation. Fruit production was estimated using the same sampling method used for natural fruit production, but subsamples were increased to 10 . No significant differences were found among plants for cross-pollination (ANOVA: $\mathrm{p}=0.88$, among $\mathrm{ms}=0.14$, within $\mathrm{ms}=$ 0.48 , $\mathrm{df}=4,45$ ), self-pollination (ANOVA: $\mathrm{p}=0.36$, among $\mathrm{ms}=0.68$, within $\mathrm{ms}=0.61$, $\mathrm{df}=4,45$ ), or unmanipulated flowers (ANOVA: $\mathrm{p}=0.78$, among $\mathrm{ms}=0.26$, within $\mathrm{ms}=$ 0.60 , $\mathrm{df}=4,45$ ). For each 100 flowers, the mean number of fruits derived from cross- 
pollination was $12.7 \pm 0.1(n=50)$; the mean number of fruits from self-pollinated flowers was $13.7 \pm 0.8(n=50)$, and the mean number of fruits in unmanipulated flowers was $2.5 \pm 0.7(n=50)$.

These results show that Eriogonum grande var. rubescens is self-compatible, but requires insect visitation for maximum fruit (i.e. seed) set. Although natural fruit set (range $=5.7-10.7$ per 100 flowers) is relatively low, experimental cross-pollination resulted in only 12.7 fruits per 100 flowers, suggesting that other factors may be limiting fruit production in Eriogonum grande var. rubescens.

\section{Erysimum ammophilum A. A. Heller (coast wallflower), Brassicaceae}

Erysimum ammophilum is a suffrutescent, perennial herb that occurs on Santa Rosa Island and at Monterey Bay (Munz and Keck 1963; Munz, 1974; Price 1993). Its ecological distribution has been described as coastal sand dunes, in association with coastal strand communities (Munz and Keck 1963; Munz 1974; Price 1993). Erysimum ammophilum is not present on Santa Cruz Island.

\section{Ground surveys.}

We found no historical records of Erysimum ammophilum for Santa Rosa Island. All potential habitat was searched, and two small populations of 6-8 plants each were found. The plants were about $2 \mathrm{dm}$ high, and more or less decumbent. Both populations were on stabilized sand dunes, with Lupinus albifrons, Atriplex californica, Lessingia filaginifolia, Ambrosia chamissonis, Abronia umbellata, Erodium cicutarium, Bromus madritensis, and $B$. diandrus.

Reproductive Biology.

Plants of Erysimum ammophilum range from 5 to $60 \mathrm{~cm}$ tall (Price 1993). Flowers are bisexual, radial, and are composed of 4 bright yellow petals, 6stamens, and 1 pistil (Munz and Keck 1963; Munz, 1974; Price 1993). Plants in both Santa Rosa Island populations were blooming and forming fruits in late April.

\section{Erysimum insulare E. Greene ssp. insulare (island wallflower), Brassicaeae}

Erysimum insulare ssp. insulare, a suffrutescent, perennial herb, occurs on Anacapa, Santa Cruz, Santa Rosa, and San Miguel islands (Munz and Keck 1963; Munz 1974; Junak et al. 1995). Its ecological distribution has been described as coastal cliffs and rocky slopes, in association with chaparral and coastal scrub communities (Munz and Keck 1963; Munz 1974; Price 1993; Junak et al. 1995).

\section{Ground surveys.}

Erysimum insulare ssp. insulare was collected on Santa Rosa Island in 1930, 1939 , and 1941, but subsequent taxonomic work showed the specimens to be either $E$. capitatum or E. suffrutescens. An E. insulare collection was made at Skunk Point in 1991 , but we could not relocate any plants there in 1994 or 1995 . We searched all potential habitats in 1994 and 1995, and found three populations on steep, sandy, northto northeast-facing bluffs, in coastal bluff scrub vegetation. Two of the populations were small, consisting of about 20 plants each, while the third consisted of more than 100 
individuals. All plants were multi-branched and decumbent, ranging from 1-2 dm in height. Commonly associated species included Isocoma menziesii, Eschscholzia californica, Bromus diandrus, Distichlis spicata, Castilleja affinis, C. mollis, and Lupinus albifrons. Plant density was counted in the largest Santa Rosa population in 1994, and more detailed data were collected in the same population in 1996.

The single site on Santa Cruz Island, a rock located in the bay at Willows Anchorage, was inaccessible. Observations (in May and July 1996) of the landward side, using binoculars, failed to reveal any plants that could be unambiguously identified as members of the genus Erysimum.

\section{Population census.}

The largest population on Carrington Point was sampled in May 1996 to determine plant density and flowering and fruiting characteristics. The area inhabited by this population is roughly $210 \times 40 \mathrm{~m}$ in area, on a north-facing steep (25-35 ) slope. Plants are scattered parallel to the bluff contours on the upper one-third of the slope, generally clustered around fine-grained sandstone outcrops that are exposed every $10-20 \mathrm{~m}$ along the contour of the slope. Soils are a fine sand with dark organic staining on the surface horizon. Ungulate trails traverse the slope about every $2-3 \mathrm{~m}$, and scattered deer scat and cow droppings were seen throughout the site.

All plants rooted within five randomly placed $5 \times 20$ meter transects were counted. For each plant, we measured crown length (the longest dimension of living leaf canopy, excluding fruits that extend beyond the canopy), and width (mean width perpendicular to the length measurement). For two randomly chosen plants per transect, we measured stem diameter at ground level, we counted inflorescences, and for three randomly chosen inflorescences, counted numbers of fruits, flowers, and seeds. Mean density was calculated for the population, flowering and fruiting data were summarized, and crown area (length $\mathrm{x}$ width) and stem diameter were averaged for the site. These data are presented in Table 5. Regression analyses were performed to determine whether stem diameter or crown area can be used as a convenient field measurement to predict the number of inflorescences per plant. Likewise, regressions investigated whether stem diameter, crown area or numbers of inflorescences were reliable predictors of numbers of flowers per inflorescence.

Table 5. Summary of Erysimum insulare ssp. insulare density, and vegetative and flowering data collected Spring 1996.

\begin{tabular}{||l|c|c|c||}
\hline \hline Parameters & Mean \pm SD & Median & Range \\
\hline Density: Live plants / plot $(n=216)$ & $43.2 \pm 23.32$ & 30 & $23-77$ \\
Dead plants / plot $(n=9)$ & $1.8 \pm 1.3$ & 2 & $0-3$ \\
Crown - Area $(n=217)$ & $1455.29 \pm 2424.67$ & 515.50 & $12-15.616$ \\
Stem Diameter $(n=10)$ & $14.13 \pm 7.74$ & 13.41 & $5.77-30.04$ \\
Number of Inflorescences $(n=10)$ & $39.40 \pm 56.68$ & 14.00 & $3-178$ \\
Fruits per Inflorescence $(n=30)$ & $18.57 \pm 7.57$ & 18.5 & $3-34$ \\
\hline
\end{tabular}


A total of 216 live plants were counted at the site (Table 5), with a mean of $4.32 \pm$ 2.33 plants $/ \mathrm{m}^{2}$ ( $n=5$ transects). A total of $59.12 \%$ of all live plants were flowering in 1996 . Dead plants a veraged $0.18 \pm 0.13$ plants $/ \mathrm{m}^{2}(\mathrm{n}=3$ transects). Mean inflorescences per plant were $39.40 \pm 56.68$, with a mean of $18.57 \pm 7.57$ fruits perinflorescence. Crown area averaged $1455.29 \pm 2424.67 \mathrm{~cm}^{2}$, and mean stem diameter was $14.13 \pm 7.74 \mathrm{~mm}$.

Regression results indicated that no measure of plant size predicts the number of flowers per inflorescence (Pearson's multiple $r$ : stem diameter $r=0.044$, crown area $r=$ 0.340 , number of inflorescences $r=0.174)$. Stem diameter is a weak predic tor of numbers of inflorescences per plant $(r=0.556)$. However, there is a positive and significant relationship between crown area and the number of inflorescences per plant (Pearson's multiple $r=0.925$ ). Therefore, crown area should be used as the best measure of plant size in future sampling.

\section{Reproductive Biology.}

Plants of Erysimum insulare ssp. insulare range from 5 to $60 \mathrm{~cm}$ tall (Price 1993; Junak et al. 1995). Flowers are bisexual, radial, and composed of four yellow petals, six stamens, and one pistil (Munz and Keck 1963; Munz, 1974; Price 1993; Junak et al. 1995). Seed production under natural conditions was estimated from 10 randomly sampled plants in census plots on Santa Rosa Island. Three fruits were randomly removed from each of ten plants. All fruits produced seeds. The mean number of seeds per fruit was $28.2 \pm 2.2(n=30)$.

\section{Helianthemum greenei B.L.Rob (island rush-rose), Cistaceae}

Helianthemum greenei is a subshrub with a distribution on Santa Catalina, Santa Cruz, Santa Rosa, and San Miguel islands (McMinn 1964; Munz and Keck 1963; Munz 1974; Junak et al. 1995). Its ecological distribution has been generally described as rocky soils of burned sites, ridge tops, slopes, and grassy hillsides, in association with chaparral, coastal scrub, oak woodland, grassland, and pine forest communities (Munz 1974; McClintock 1993; Junak et al. 1995).

\section{Ground surveys.}

Helianthemum greenei was collected on Santa Rosa in 1937, but no information on location or population condition was given. A second, unverified location was listed in field notes from 1967, and this location was searched in 1994 and 1996. No $H$. greene $i$ were found there or in potential habitats in other areas.

We surveyed 14 populations on Santa Cruz Island. Population size among 14 sites ranged from 3 to more than 1,000 plants (mean $=196 \pm 98$, median $=7.5$ ), was clearly related to recent fire history. Four populations were surveyed in an area south of China Harbor that had been burned in December 1994 (Junak et al. 1995).

Helianthemum greenei was the dominant understory species in 1996, with a mean population size of $663 \pm 208$ (median $=750)$. Mean population size in the 10 unburned sites was $9 \pm 3$ (median $=6$ ). Three of the burned sites south of China Harbor were sampled for density, using twenty $0.25 \mathrm{~m}^{2}$ plots placed at $1 \mathrm{~m}$ intervals along a $20 \mathrm{~m}$ transect through each popula-tion. Mean density (plants $/ 0.25 \mathrm{~m}^{2}$ ) was $2.4 \pm 0.4,1.4 \pm$ 0.4 , and $3.2 \pm 0.5$, respectively. 
Most populations generally occurred on flats or moderate, north-facing slopes at elevations ranging between 100 and $430 \mathrm{~m}$. Typical substrates are rocky soils derived from either metamorphic or volcanic rocks. No seedlings were observed in any population, including populations near China Harbor, suggesting that most plants were recruited in the first rainy season (1994-1995) after the fire.

The most common associates included Arctostaphylos insularis, Arctostaphylos tomentosa, Baccharis pilularis, Ceanothus arboreus, Heteromeles arbutifolia, Pinus muricata, Quercus pacifica, and Quercus parvula. These taxa are characteristic of insular pine forest and chaparral communities (Philbrick and Haller 1977; Bjorndalen 1978). Although vegetative cover in unburned sites generally exceeded $60 \%$, most plants occurred in small, open sites among the dominant taxa. Cover was less than $30 \%$ at burned sites near China Harbor. Vegetation in 1996 was dominated primarily by seedlings of Pinus muricata, stump sprouts and seedlings of Arctostaphylos tomentosa, stump sprouts of Quercus parvula, and reproductively mature plants of Lotus dendroideus, Lotus grandiflorus, and Helianthemum greenei. These observations suggest that Helianthemum greenei occurs primarily in sites free from competition for light and that its recruitment is enhanced by fire, either through breaking of seed dormancy or through a requirement for non-competitive conditions at the seedling stage.

\section{Reproductive Biology.}

Flowers of Helianthemum greenei are bisexual, radial, and composed of five yellow petals, many stamens, and one pistil (Daoud and Wilbur 1965). General observations during the course of this study suggest that flowers of Helianthemum greenei are visited by small flies and both nectar- and pollen-gathering bees.

Reproductive biology was assessed by estimating the number of flowers per plant in six populations on Santa Cruz Island (Cebada, Centinela 1, Centinela 2, China 1, China 2, and China 3). The number of plants in the first three sites were 3,2 , and 5 respectively, but population size at sites south of China Harbor ranged from 150 to over 1,000 . In the latter 3 populations, random samples of 20 plants each were scored for flower and seed production. Flower production was assessed in April. Random samples of 20 fruits per population in May were used to assess the number of seeds per fruit.

Mean number of flowers per plant was: $100.3 \pm 8.7$ at Cebada $(n=3), 97.5 \pm 4.5$ at Centinela $1(n=2), 112.2 \pm 14.7$ at Centinela $2(n=5), 57.8 \pm 7.2$ at China $1(n=20)$, $53.1 \pm 7.6$ at China $2(n=20)$, and $50.5 \pm 7.8$ at China $3(n=20)$. No significant differences were found in seeds per fruit among the six populations (ANOVA: $p=0.93$, among $\mathrm{ms}=0.21$, within $\mathrm{ms}=0.79, \mathrm{df}=5,114)$. The overall mean number of seeds per fruit was $9.5 \pm 0.3(n=120)$.

Self-compatibility was estimated from the number of seeds per fruit obtained from controlled crosses performed on three plants at the Santa Barbara Botanic Garden. Self-compatibility was estimated by pollinating 10 flowers on each plant, using pollen from the same flower or flowers on the same plant. The level of self-pollination was estimated from 10 more flowers on each of the same plants, which were covered with nylon mesh to exclude pollinators. Flowers were randomized with respect to each of the two treatments to avoid potential position effects. 
No significant differences were found among plants for either self-pollination (ANOVA: $\mathrm{p}=0.37$, among $\mathrm{ms}=1.60$, within $\mathrm{ms}=1.54$, $\mathrm{df}=2,27$ ) or unmanipulated flowers (ANOVA: $\mathrm{p}=0.16$, among $\mathrm{ms}=2.70$, within $\mathrm{ms}=17.18, \mathrm{df}=2,27$ ). The overall mean number of seeds per fruit derived from self-pollination was $11.2 \pm 0.2(\mathrm{n}=$ 30). The mean number of seeds per fruit from unmanipulated flowers was $4.6 \pm 0.7$ ( $n$ $=30$ ).

These studies show that Helianthemum greenei is self-compatible and that seed set can occur in the absence of insect visitation. However, the difference between seed set in unmanipulated flowers (4.6) and self-pollinated flowers (11.2) suggests that insect pollination may enhance seed set under natural conditions.

\section{Heuchera maxima Greene (island alumroot), Saxifragaceae}

Heuchera maxima is a perennial herb restricted to Anacapa, Santa Cruz, and Santa Rosa islands (Munz and Keck 1963; Munz 1974; Junak et al. 1995). Its ecological distribution has been described as coastal bluffs, shaded north-facing slopes, and canyon walls, in association with coastal scrub, oak woodland, pine forest, and riparian communities (Munz 1974; Elvander 1993; Junak et al. 1995).

\section{Ground surveys.}

Heuchera maxima was known to exist in four canyons on Santa Rosa Island, from botanical surveys conducted from 1939 through 1982 . We relocated it in 3 of those 4 canyons. Heuchera maxima is scattered in Cherry (two populations), Windmill (eight populations) and Lobos canyons (17 populations) on north-facing headwalls and nearly vertical cliff faces in areas out of reach of ungulates. The fourth population was described from Ranch Canyon in 1939. Our searches failed to locate it in Old Ranch Canyon or canyons near the current ranch house; the most likely localities for the 1939 observation. Populations ranged in size from 1 to more than 150 plants each; most populations had individuals of all sizes and showed evidence of flowering in the 1996 growing season.

Heuchera maxima is known historically from 16 locations on Santa Cruz Island. We relocated 7 populations. The others were in inaccessible areas and were not surveyed. Population size ranged from 15 to more than 170 plants (mean $=46 \pm 21$, median $=23$ ). Most populations occurred on sedimentary or volcanic rock ledges and cliff faces at elevations between 45 and $150 \mathrm{~m}$. Most sites were mesic and usually on north-facing slopes or drainages, with cover ranging from $20 \%$ to over $100 \%$ cover. Most populations included a wide range of plant sizes, ranging from seedlings to flowering and fruiting plants.

On Santa Cruz Island, the most common associates included Heteromeles arbutifolia, Prunus ilicifolia ssp. lyonii, Quercus agrifolia, often with an understory of Woodwardia fimbriata, which are characteristic of oak woodland (Philbrick and Haller 1977; Minnich 1980; Junak et al. 1995). The most common associates on Santa Rosa Island included Coreopsis gigantea, Dudleya greenei, Heteromeles arbutifolia, Mimulus flemingii, and Woodwardia fimbriata. These species are characteristic of insular coastal scrub and chaparral communities (Philbrick and Haller 1977; Minnich 1980). 
Reproductive Biology.

The inflorescences of Heuchera maxima are paniculate with many, small flowers, each bisexual, radial, and composed of five white to pinkish petals, five stamens, and one pistil. We were unable to make general observations of pollination in natural populations, but small bees and flies were observed visiting plants in the Santa Barbara Botanic Garden.

Reproductive biology was assessed by estimating the number of seeds per flower in three populations on Santa Cruz Island (Pelican, Tinkers, Stanton) and three on Santa Rosa Island (Lobo 1, Lobo 2, and Lobo 3). Seeds were counted in each of 20 fruits, randomly sampled from each population.

Significant differences were found in seeds per fruit among the six populations (ANOVA: $\mathrm{p}=0.01$, among $\mathrm{ms}=2.65$, within $\mathrm{ms}=0.76, \mathrm{df}=5,114$ ). Mean seed set for 20 flowers in each of the populations was $29.5 \pm 2.2$ at Pelican, $33.5 \pm 1.6$ at Tinkers, $23.7 \pm 2.1$ at Stanton, 31.7 \pm 2.1 at Lobo $1,25.3 \pm 2.0$ at Lobo 2, and 28.3 \pm 1.8 at Lobo 3. Overall seed set among the six populations was $28.8 \pm 0.8(n=120)$.

Self-compatibility was estimated from controlled crosses performed on five plants at the Santa Barbara Botanic Garden. Ten flowers on each plant were selfpollinated by hand, using pollen from the same flower or flowers on the same plant. The level of self-pollination was estimated from 10 additional flowers on each of the same plants, which were covered with nylon mesh to exclude pollinators. Ten more flowers on each plant were left exposed, to estimate the level of seed production under relatively natural conditions of pollinator visitation at the Santa Barbara Botanic Garden. Flowers were randomized with respect to both controlled crosses and self-pollination treatments, to avoid potential position effects.

No significant differences were found among plants for either self-pollination (ANOVA: $\mathrm{p}=0.75$, among $\mathrm{ms}=0.12$, within $\mathrm{ms}=0.25$, $\mathrm{df}=4,45$ ) or unmanipulated flowers (ANOVA: $\mathrm{p}=0.08$, among $\mathrm{ms}=0.18$, within $\mathrm{ms}=2.35$, $\mathrm{df}=4,45$ ). The mean number of seeds per fruit derived from self-pollination was $34.0 \pm 0.8(n=50)$; the mean number of seeds per fruit from unmanipulated flowers was $7.3 \pm 0.9(n=50)$. No significant differences were found among plants that were exposed to natural pollinators at the Santa Barbara Botanic Garden (ANOVA: $\mathrm{p}=0.38$, among $\mathrm{ms}=0.62$, within $\mathrm{ms}=$ $0.57, \mathrm{df}=4,45)$. The mean number of seeds per exposed flower was $31.6 \pm 1.2(\mathrm{n}=$ 50).

These studies show that Heuchera maxima is self-compatible, but the low seed set (7.3 per flower) in flowers from which insects were excluded suggests that plants are dependent on insect visitation for maximum seed production (28.8 per flower under natural conditions). 


\section{Jepsonia malvifolia (Greene) Small (island jepsonia), Saxifragaceae}

Jepsonia malvifolia is a perennial herb with a distribution on Guadalupe Island (Baja California) and all California Channel Islands except Anacapa, Santa Barbara, and San Miguel (Munz and Keck 1963; Ornduff 1969, 1970; Munz 1974; Junak et al. 1995). Its ecological distribution has been described as occurring on coastal bluffs and north-facing slopes in association with chaparral, coastal scrub, oak woodland, and pine forest (Munz 1974; Elvander 1993; Junak et al. 1995). Notably, plants flower during the fall and winter months, then develop leaves during the winter and spring months.

\section{Ground surveys.}

Santa Rosa Island populations of Jepsonia malvifolia are known from surveys and collections made in 1930,1960, 1973 and the early 1990's. We relocated populations in each of these previously known areas, Becher's Bay, the Black Mountain chaparral, and the South Point chaparral. Population trend is impossible to assess because earlier surveyors did not note population size or condition. We conducted our surveys during the 1995-1996 flowering season, when vegetative plants were still dormant. Jepsonia malvifolia is scattered in patches on the north-facing slopes of Beecher's Bay between Water Canyon and the east end of the Torrey pine grove. It occurs in small grassy openings within the grove. It is scattered as individuals and as clumps of 5-40 flowering plants in size throughout the sparse grassland on the lower slopes and upper margins of the Adenostoma fasciculatum chaparral on slopes facing $320-340^{\circ}$. It is not present in eroded areas where bedrock is exposed or the soil lichen crust is no longer intact. Such eroded areas generally occur on all the nearly level to gentle north-sloping ridges in the chaparral between Water Canyon and the pines, and on about $60 \%$ of the steeper north-facing slopes below the ridges. Jepsonia malvifolia is also absent from areas where vegetation cover exceeds $80 \%$, and rare to absent in areas where grass litter has accumulated as a thatch on the soil surface. Such thick grass cover generally occurs at the toes of the alluvial slopes below the chaparral and pines along the bay. Associated grassland species include Bromus spp., Vulpia spp., Nassella pulchra, and Erodium cicutarium. Associated chaparral shrubs include Adenostoma fasciculatum and Quercus pacifica. We found one population of about 140 flowering individuals on a nearly vertical, cryptogamic-encrusted canyon face about six feet above the stream bottom. No other populations were found, although all canyons were searched. We counted over 300 flowering plants in the Beecher's Bay area. Given the ratio of flowering to vegetative plants (see below), there are probably several thousand plants in the area.

Population distribution in the Black Mountain chaparral is much more clumped, and the clumps are separated from one another by 100's of meters. We found nine populations in the Black Mountain area, ranging in size from 5 to 106 flowering plants each $($ mean $=41.1 \pm 31.5$, median $=37)$. As in the Beecher's Bay area, J. malvifolia was absent where soil erosion was severe - the situation throughout most of the Black Mountain chaparral community. Jepsonia malvifolia is even more sparse in the South Point chaparral. There we found seven populations ranging from 8 to 19 flowering plants in size $($ mean $=14.2 \pm 3.7$, median $=16)$. One population of over 100 flowering plants (probably over 300 plants) was located in a tributary to lower Cherry Canyon, on a west-facing canyon wall similar to the Becher's Bay canyon locality. 
Jepsonia malvifolia was known or collected from 12 Santa Cruz Island sites prior to 1995 . We resurveyed eight of these sites; the remaining four sites were not visited because of constraints on accessibility. The eight populations ranged in size from 13 to over 53 plants mean $=30.5 \pm 5$, median $=31.5$ ). Most populations occurred on finegrained soils of bluffs and north-facing slopes at elevations between 15 and $320 \mathrm{~m}$. Substrates are derived from either metamorphic or volcanic rocks. Most sites were generally characterized by a lack of shrubs or trees. Some relatively small grassland sites, often less than $100 \mathrm{~m}^{2}$, were generally located within chaparral (Philbrick and Haller 1977; Bjorndalen 1978). The most common herbaceous associates include Bromus hordeaceus, Dodecatheon clevelandii, Erodium spp., Vulpia spp., and Lessingia filaginifolia, which are characteristic of Mediterranean grassland communities. The most common shrubs included Adenostoma fasciculatum, Arctostaphylos insularis, Heteromeles arbutifolia, and Quercus pacifica.

\section{Population census.}

At least three $50 \times 50 \mathrm{~cm}$ permanent demography plots were established at each of nine sites, November 21 - December 5, 1995. Six sites were sampled on Santa Rosa and three on Santa Cruz Island. Plots were subjectively located in spots with at least five flowering plants per $50 \times 50 \mathrm{~cm}$ plot; objectives were to sample at least 15 flowering plants per site. Table 6 shows the habitat types, plot numbers, and numbers of plants sampled per site on each island during the November - February flowering and vegetative seasons. All flowering stems in the plots were mapped. Number of flowering stems, and the number of buds, flowers, and fruits per stem were counted. Stem height was measured. Plants were scored as either pins (female) or thrums (male). Plots were revisited February 9-12, 1996, and vegetative plants were added to the study. All plants in each plotwere mapped and the numbers of leaves were recorded. The length and width of each leaf was measured to the nearest millimeter, and notes were made indicating whether plants had flowered in 1995-1996. When numerous, very small plants (leaves ca. $0.2 \times .0 .2 \mathrm{~cm}$, corms $1-2 \mathrm{~mm}$ ) occurred within a plot, the plot was divided into twenty-five $1 \times 1 \mathrm{dm}$ squares and the tiny plants were tallied in two categories: 1-leaf and 2-leaves. These plants are probably firstyear seedlings or two-year old plants; they were counted as seedlings. These plots will be re-sampled in 1996-1997 to get estimates of population variability between years. 
Table 6. Flowering and vegetative Jepsonia malvifolia plants sampled in demography plots on Santa Cruz (SCI) and Santa Rosa (SRI) islands, Nov. 1995-Feb. 1996.

\begin{tabular}{|c|c|c|}
\hline Island - Community - Site & Plot\# & $\begin{array}{l}\text { \# Plants sampled } \\
\text { persite: } \\
1995 \text { - } 1996 \text { season }\end{array}$ \\
\hline $\begin{array}{l}\text { SRI - Grassland - Site } 1 \text { - Canyon } 7 \\
\text { Ridge } \\
\text { Ridge }\end{array}$ & $\begin{array}{l}1111,1112,1113 \\
1109,1110,1124\end{array}$ & $\begin{array}{l}141+35+47=223 \\
26+36+19=81\end{array}$ \\
\hline $\begin{array}{l}\text { SRI - Chaparral - Site 3-Telephone } \\
\text { Road } \\
\qquad \text { Site } 4 \text {-Main Road }\end{array}$ & $\begin{array}{l}1117,1118,1119 \\
1114,1115,1116 \\
\end{array}$ & $\begin{array}{l}19+13+43=75 \\
21+25+19=65\end{array}$ \\
\hline $\begin{array}{cc}\text { SRI - Canyon - } & \text { Site } 5 \text { - Torrey Pines } \\
& \text { Canyon } 6 \\
& \text { Site } 6 \text { - Cherry Canyon }\end{array}$ & $\begin{array}{l}1125,1126,1127 \\
1120,1122,1123\end{array}$ & $\begin{array}{l}29+64+11=104 \\
12+17+76=105\end{array}$ \\
\hline $\begin{array}{l}\text { SCI - Chaparral openings } \\
\qquad \text { Site } 1 \text { - Valley Ridge } \\
\text { Site } 2 \text { - Coches }\end{array}$ & $\begin{array}{l}420823,420875,420923 \\
420803,420887,420888, \\
420897,420909,420913, \\
420948,420969 \\
420834,420838,420910, \\
420963,420970\end{array}$ & $\begin{array}{l}13+11+22=46 \\
1+1+2+ \\
4+1+2+ \\
1+5=17 \\
8+2+7+ \\
4+5=26\end{array}$ \\
\hline
\end{tabular}

Pig rooting was a significant source of Jepsonia mortality in $38 \%$ of the Santa Cruz Island plots. No plots were affected by rooting at Christy. At Coches, $60 \%$ of the plots were dug up by pigs, and 20 to $100 \%$ of the plants in those plots were lost. All three plots at Valley Ridge were affected, with 73,82 , and $92 \%$ mortality each.

In addition to permanent plots, Jepsonia density was sampled in plots placed along transects at two grassland and two chaparral sites on Santa Rosa (canyon sites were not sampled due to steep topography), and at all three Santa Cruz study sites. Population boundaries were located and mapped in the field on USGS topographic maps November 2- December 5, 1995, and again February 9-13, 1996. Each population site was stratified into two (Santa Cruz Island) or three (Santa Rosa Island) areas depending on topography and total area occupied. Jepsonia density was sampled in plots placed along one randomly placed $20 \times 1 \mathrm{~m}$ transect per site stratum. All plants rooted within plots were counted in three categories: very small "seedling" non-flowering plants, non-flowering 1-, 2-, and 3leaved plants, and flowering 1,2, and 3-leaved plants. Table 7 shows Jepsonia density summarized by seedling, vegetative, and flowering plants for the two islands. 
Table 7. Jepsonia malvifolia seedling, vegetative and flowering plant density for plots sampled on Santa Rosa and Santa Cruz islands, February, 1996.

\begin{tabular}{|c|c|c|c|}
\hline Island, habitat, \& site & Vegetative plants & Flowering plants & Seedlings \\
\hline \multicolumn{4}{|l|}{ SRI Grassland } \\
\hline $\begin{array}{l}\text { Site 1: } \\
\text { Canyon } 7 \text { Ridge }\end{array}$ & $\begin{array}{l}22.33 \pm 24.15 \\
0-97.5 \\
15.75\end{array}$ & $\begin{array}{l}0.48 \pm 1.29 \\
0-6.5 \\
0\end{array}$ & $\begin{array}{l}1.18 \pm 1.67 \\
0-5.0 \\
0.5\end{array}$ \\
\hline $\begin{array}{l}\text { Site 2: } \\
\text { Canyon } 5 \text { Ridge }\end{array}$ & $\begin{array}{l}7.95 \pm 9.20 \\
0-32 \\
4.25\end{array}$ & 0 & 0 \\
\hline \multicolumn{4}{|l|}{ SRI Chaparral } \\
\hline $\begin{array}{l}\text { Site 3: } \\
\text { Telephone Road }\end{array}$ & $\begin{array}{l}2.65 \pm 5.16 \\
0-22.5 \\
0\end{array}$ & $\begin{array}{l}0.72 \pm 1.45 \\
0-6 \\
0\end{array}$ & $\begin{array}{l}0.50 \pm 1.69 \\
0-8.5 \\
0\end{array}$ \\
\hline $\begin{array}{l}\text { Site 4: } \\
\text { Main Road }\end{array}$ & $\begin{array}{l}3.42 \pm 6.19 \\
0-25.5 \\
0.5\end{array}$ & $\begin{array}{l}0.35 \pm 0.88 \\
0-4.5 \\
0\end{array}$ & $\begin{array}{l}0.08 \pm 0.19 \\
0-0.5 \\
0\end{array}$ \\
\hline \multicolumn{4}{|l|}{ SCI Chaparral } \\
\hline $\begin{array}{l}\text { Site 7: } \\
\text { Valley Ridge }\end{array}$ & $\begin{array}{l}1.80 \pm 2.31 \\
0-8 \\
0.75\end{array}$ & 0 & $\overline{0}$ \\
\hline $\begin{array}{l}\text { Site 8: } \\
\text { Coches }\end{array}$ & $\begin{array}{l}1.00 \pm 2.08 \\
0-7.5 \\
0\end{array}$ & $\begin{array}{l}0.05 \pm 0.22 \\
0-1.0 \\
0\end{array}$ & 0 \\
\hline $\begin{array}{l}\text { Site 9: } \\
\text { Christy }\end{array}$ & $\begin{array}{l}7.13 \pm 9.64 \\
0-37.5 \\
3.25\end{array}$ & $\begin{array}{l}0.05 \pm 0.22 \\
0-1.0 \\
0\end{array}$ & 0 \\
\hline
\end{tabular}

${ }^{1}$ Data presented are: mean plant density $\pm \mathrm{SD}$, range, and median plant density per $\mathrm{m}^{2}$, counted in plots $(n=30, S R I ; n=20, S C I)$.

An ANOVA was performed to test for differences in seedling, vegetative and flowering plant densities among populations sampled on each island. On Santa Rosa Island there were no significant differences among sites $(p=0.05)$ in flowering plant density. However, the grassland habitat of the Canyon 7 Ridge had significantly higher vegetative plant density than Main Road and Telephone Road chaparral populations ( $p<$ 0.001). The Canyon 5 Ridge grassland habitat supported no flowering plants in 1995-

1996. Canyon 7 also had significantly higher numbers of seedlings than Main $\operatorname{Road}(\mathrm{p}=$ 0.003), but it was not significantly different from the remaining site at Telephone Road. Canyon 5 had no seedlings.

No seedlings were present along any of the Santa Cruz Island transects, and Valley Ridge had no flowering plants. Coches and Christy did not differ significantly in the number of flowering plants present $(p=0.05)$; both had extremely low flowering plant density. However, the Christy population had significantly higher vegetative plant density than Coches $(p=0.002)$ and Valley Ridge $(p=0.006)$. 
The ratios of flowering to vegetative plants on Santa Rosa Island were 0.02 (Canyon 7), 0.10 (Main Road), and 0.27 (Telephone Road). Santa Cruz ratios were 0.007 at Christy and 0.05 at Coches; there were no flowering plants at Valley Ridge. Generally, there is a positive relationship between the total number of flowering plants and the total number of vegetative plants at each Santa Rosa site where flowering plants were present. However, flowering plant density is a fairly good predictor of vegetative plant density only at Telephone Road $(n=30$ plots, Pearson's multiple $r=0.925, p<$ 0.001). For the two Santa Cruz sites with flowering plants in the plots, there was no significant relationship when site data were pooled. However, at Coches there was a significant and fairly strong positive relationship ( $n=20$ plots, Pearson's $r=0.734, p<$ 0.001 ), while at Christy, flowering plant density was a poor predictor of vegetative plant density in the same growing season $(n=20$ plots, Pearson's $r=0.314, p=0.177$ ).

The plant community present at each site was sampled in five $50 \times 50 \mathrm{~cm}$ quadrats randomly located along the 20 -m population census transects. Ocular cover estimates were made in the categonies of percent total vegetation, litter, rock, bare ground, and cryptobiotic crust. All plant species rooted in the quadrat were listed. Table 8 shows habitat cover sampled at each study site. Santa Rosa sites ranged from a low total vegetative cover of $46.33 \%$ at Telephone Road to a high of $83.6 \%$ at Canyon 5. Litter cover was similar at all sites, but duff varied from none at Canyon 5 to $1.73 \%$ cover at Main Road. Percent rock cover varied several-fold among sites, with $14.6 \%$ exposed at Main Road, $6.3 \%$ and $4.3 \%$ at Telephone Road and Canyon 7, respectively, and only $0.20 \%$ at Canyon 5 . Soil crust reached a low of $1.20 \%$ cover at Canyon 5 , whereas it ranged between $4.33 \%$ (Telephone Road) and $7.97 \%$ (Canyon 7 ) at the other three sites. In all of these parameters, Canyon 7 is more nearly like the chaparral sites than it is like the other grassland site. This could be evidence that this site represents a recent community shifting or an ecotone where grassland species have moved into what used to be dominated by woodland-chaparral vegetation. Ground cover may be an important factor influencing differences between Jepsonia densities observed at the two grassland sites. 
Table 8. Habitat cover estimated within Jepsonia malvifolia populations on Santa Rosa and Santa Cruz islands, February 1996 (mean \pm SD).

\begin{tabular}{|c|c|c|c|c|c|c|}
\hline $\begin{array}{c}\text { Island, } \\
\text { habitat \& site }\end{array}$ & $\begin{array}{c}\text { Total } \\
\text { vegetation }\end{array}$ & Litter & $\begin{array}{c}\text { Bare } \\
\text { Ground }\end{array}$ & Rock & Crust & Duff \\
\hline \multicolumn{7}{|l|}{$\begin{array}{l}\text { SRI } \\
\text { Grassland }\end{array}$} \\
\hline $\begin{array}{l}\text { Site 1: } \\
\text { Cyn } 7 \text { Ridge }\end{array}$ & $69.6 \pm 23.0$ & $13.0 \pm 8.1$ & $5.1 \pm 7.1$ & $4.3 \pm 15.4$ & $8.0 \pm 9.5$ & $0.1 \pm 0.3$ \\
\hline $\begin{array}{l}\text { Site 2: } \\
\text { Cyn } 5 \text { Ridge }\end{array}$ & $83.6 \pm 9.8$ & $11.6 \pm 7.3$ & $3.4 \pm 7.5$ & $0.2 \pm 0.8$ & $1.2 \pm 1.9$ & 0 \\
\hline \multicolumn{7}{|l|}{$\begin{array}{l}\text { SRI } \\
\text { Chaparral }\end{array}$} \\
\hline $\begin{array}{l}\text { Site 3: } \\
\text { Telph. Rd. }\end{array}$ & $63.0 \pm 22.9$ & $15.1 \pm 10.6$ & $\begin{array}{l}11.4 \\
\pm 14.0\end{array}$ & $6.3 \pm 11.6$ & $4.3 \pm 5.4$ & $1.6 \pm 2.5$ \\
\hline $\begin{array}{l}\text { Site 4: } \\
\text { Main Road }\end{array}$ & $46.3 \pm 31.0$ & $15.3 \pm 14.8$ & $\begin{array}{l}17.1 \\
\pm 25.1\end{array}$ & $\begin{array}{l}14.6 \\
\pm 26.4\end{array}$ & $6.7 \pm 8.0$ & $1.7 \pm 2.7$ \\
\hline \multicolumn{7}{|l|}{$\begin{array}{l}\text { SCI } \\
\text { Chaparral }\end{array}$} \\
\hline $\begin{array}{l}\text { Site 7: } \\
\text { Valley Peak }\end{array}$ & $43.1 \pm 23.4$ & $22.6 \pm 17.0$ & $\begin{array}{l}25.7 \\
\pm 29.6 \\
\end{array}$ & $7.4 \pm 6.6$ & $0.7 \pm 0.9$ & \\
\hline $\begin{array}{l}\text { Site 8: } \\
\text { Coches }\end{array}$ & $55.9 \pm 22.3$ & $15.0 \pm 5.9$ & $\begin{array}{l}23.2 \\
\pm 21.1\end{array}$ & $3.1 \pm 3.7$ & $2.8 \pm 3.5$ & $\overline{0}$ \\
\hline $\begin{array}{l}\text { Site 9: } \\
\text { Christy } \\
\end{array}$ & $29.0 \pm 21.8$ & $19.1 \pm 3.1$ & $\begin{array}{l}16.4 \\
\pm 12.0 \\
\end{array}$ & $\begin{array}{l}23.7 \\
\pm 15.8 \\
\end{array}$ & $11.7 \pm 4.7$ & $0.1 \pm 0.3$ \\
\hline
\end{tabular}

On Santa Rosa Island the highest total vegetation cover was observed at the grassland Canyon 5 Ridge site, where litter, rock and soil crust coverages were lowest. Highest Santa Cruz Island total vegetative cover was observed at Coches. Litter and rock cover were lower there than at the other two sites. Christy had unusually high rock and soil crust cover, compared to all other sampled sites.

\section{Reproductive Biology.}

Jepsonia malvifolia is a small, herbaceous perennial, which flowers in late summer and fall and produces one to several leaves after the fruit matures (Ornduff 1969). Flowers are bisexual, radial, and composed of five white to pinkish petals, 10 stamens, and one pistil. However, the species is heterostylous (Ornduff 1961, 1969, 1970), with two floral forms (i.e., pins, with long styles and short stamens, and thrums, with short styles and long stamens). Most populations are composed of plants with ratios between pins and thrums approaching 50\% each. Although heterostyly is usually associated with a strong self-incompatibility system, the genetic system is incomplete in Jepsonia malvifolia, such that selfing or crosses between similar forms results in some seed set (Ornduff 1970). In experimental crosses under controlled conditions, Ornduff (1970) obtained 36.7 and 29.7 seeds per flower (pin and thrum flowers respectively) from crosses between floral forms. Self-pollination resulted in 6.6 and 4.4 seeds per flower respectively. Flies and small bees have been reported as effective pollinators (Ornduff 1969). 
Reproductive biology was assessed by estimating the number of fruits per plant in three populations on Santa Cruz Island (Coches, Valley, and Christy). Although the number of flowering plants at each site ranged from 18 to 24 , some plants in each population had completed flowering and fruiting at the time they were sampled in December 1995. The num-ber of flowers and fruits (on both islands) and seeds per developed fruit (Santa Cruz only) were recorded for all plants rooted within plots. Table 9 summarizes data on proportions of pins and thrums, and the percent fruit set in plots on Santa Rosa and Santa Cruz islands.

Table 9. Fruit set and pin:thrum plant ratios for Jepsonia malvifolia in demography plots sampled on Santa Rosa and Santa Cruz islands, November December 1995.

\begin{tabular}{|c|c|c|c|c|c|}
\hline $\begin{array}{c}\text { Island, } \\
\text { habitat \& site }\end{array}$ & $\begin{array}{l}\text { \# pin } \\
\text { plants }\end{array}$ & $\begin{array}{l}\% \text { fruit set: pin } \\
\text { flowers }\end{array}$ & $\begin{array}{l}\text { \# thrum } \\
\text { plants }\end{array}$ & $\begin{array}{l}\% \text { fruit set: } \\
\text { thrum flowers }\end{array}$ & $\begin{array}{l}\text { pin : thrum } \\
\text { ratio }\end{array}$ \\
\hline \multicolumn{6}{|l|}{$\begin{array}{l}\text { SRI } \\
\text { Grassland }\end{array}$} \\
\hline $\begin{array}{l}\text { Site 1: } \\
\text { Cyn } 7 \text { Ridge }\end{array}$ & 12 & $\begin{array}{l}19.15 \\
\mathrm{n}=47\end{array}$ & 3 & $\begin{array}{c}60.7 \\
n=28\end{array}$ & 3.00 \\
\hline $\begin{array}{l}\text { Site 2: } \\
\text { Cyn } 5 \text { Ridge }\end{array}$ & 9 & $\begin{array}{l}41.38 \\
\mathrm{n}=58\end{array}$ & 18 & $\begin{array}{c}59.17 \\
n=120\end{array}$ & 0.50 \\
\hline \multicolumn{6}{|l|}{$\begin{array}{l}\text { SRI } \\
\text { Chaparral }\end{array}$} \\
\hline $\begin{array}{l}\text { Site 3: } \\
\text { Telph. Rd. }\end{array}$ & 15 & $\begin{array}{l}55.21 \\
\mathrm{n}=96\end{array}$ & 6 & $\begin{array}{l}68.18 \\
\mathrm{n}=22\end{array}$ & 2.50 \\
\hline $\begin{array}{l}\text { Site 4: } \\
\text { Main Road }\end{array}$ & 8 & $\begin{array}{l}53.85 \\
\mathrm{n}=52\end{array}$ & 10 & $\begin{array}{c}71.43 \\
\mathrm{n}=56 \\
\end{array}$ & 0.80 \\
\hline \multicolumn{6}{|l|}{$\begin{array}{l}\text { SRI } \\
\text { Canyons }\end{array}$} \\
\hline $\begin{array}{l}\text { Site 5: } \\
\text { Torrey } \\
\text { Pines, Cyn } 6\end{array}$ & 23 & $\begin{array}{c}83.12 \\
n=160\end{array}$ & 21 & $\begin{array}{c}85.09 \\
n=114\end{array}$ & 1.10 \\
\hline $\begin{array}{l}\text { Site 6: } \\
\text { Cherry Cyn }\end{array}$ & 1 & $\begin{array}{c}0 \\
n=4\end{array}$ & 5 & $\begin{array}{c}29.41 \\
\mathrm{n}=17\end{array}$ & 0.20 \\
\hline \multicolumn{6}{|l|}{$\begin{array}{l}\text { SCI } \\
\text { Chaparral }\end{array}$} \\
\hline $\begin{array}{l}\text { Site 7: } \\
\text { Valley Peak }\end{array}$ & 14 & $\begin{array}{c}78.9 \\
\mathrm{n}=38\end{array}$ & 18 & $\begin{array}{c}85.4 \\
\mathrm{n}=48\end{array}$ & 0.78 \\
\hline $\begin{array}{l}\text { Site 8: } \\
\text { Coches }\end{array}$ & 6 & $\begin{array}{c}73.5 \\
\mathrm{n}=34\end{array}$ & 6 & $\begin{array}{c}68.9 \\
\mathrm{n}=45\end{array}$ & 1.00 \\
\hline $\begin{array}{l}\text { Site 9: } \\
\text { Christy }\end{array}$ & 5 & $\begin{array}{c}69.1 \\
n=68\end{array}$ & 6 & $\begin{array}{c}75.0 \\
n=68\end{array}$ & 0.83 \\
\hline
\end{tabular}

The mean number of seeds per fruit was $7.8 \pm 1.2$ (pin flowers, $\mathrm{n}=34$ ) and $7.4 \pm$ 1.0 (thrum flowers, $n=45$ ) at Coches, $10.0 \pm 1.4$ (pin flowers, $n=38$ ) and $11.4 \pm 1.0$ (thrum flowers, $n=48$ ) at Valley, and $9.2 \pm 0.9$ (pin flowers, $n=68$ ) and $9.8 \pm 0.9$ (thrum flowers, $n=68$ ) at Christy. Overall seed set per flower under natural conditions on Santa Cruz Island ranged from 7.4 to 11.4 , which is less than that observed by Ornduff $(29.7$ to 
36.7) but greater than his results from self-pollination (4.4 to 6.6). These studies suggest that fruit and seed set in Jepsonia malvifolia populations on Santa Cruz Island are less than expected and may be limited by natural pollination.

\section{Lasthenia glabrata Lindley ssp. coulteri (A. Gray) E. Greene, (Coulter goldfields). Asteraceae}

Lasthenia glabrata ssp. coulteri is a small annual found in moist alkaline sites and coastal marshes. It extends in mainland coastal locations from San Diego County to Kern County, and is found near Twentynine Palms in the Mojave Desert. It also occurs on Santa Rosa Island, the only Channel Island where it is found (Ornduff 1966, Munz and Keck 1973).

\section{Ground surveys.}

Historic collections from the salt marsh on Santa Rosa date from 1930 and 1960. Searches in 1995 and 1996 failed to find any plants. Individuals were not present in similar habitats around the lagoon at the mouth of Old Ranch Creek. However, one new location was found several hundred meters inland from the Old Ranch Creek mouth, in a moist swale between the creek and low bluffs to the north of the creek. Plants were confined to the wettest portions of the swale. A road skirts the creek levee between the swale and Old Ranch Creek. Lasthenia glabrata ssp. coulteri is absent from the road, the levee, and the creek side of the levee.

\section{Population census.}

Population density was sampled March 30, 1996. The population occupies an approximately rectangular swale of about $75 \times 30 \mathrm{~m}$, or 2250 square meters. Six $1-\mathrm{m}$ wide belt transects were located at even intervals across the swale, spanning the width of the population. Numbers of plants rooted in each transect were counted, and plants that were trampled by ungulates or damaged by insects were noted. Plant height was measured to the nearest centimeter on eleven randomly chosen individuals. A tally was kept by transect of cow trails crossing the belt transect, and general notes were made on habitat condition within the population boundaries.

The species grows in a shallow, nearly level swale at the inland edge of the Old Ranch Creek terrace, at about $6 \mathrm{~m}$ elevation. Water had been standing in the swale for at least one month previous to our visit, and the ground was still soggy during sampling. The entire area occupied by Lasthenia glabrata ssp. coulteri was heavily trampled by cattle. Hoof prints averaging $2-3 \mathrm{~cm}$ deep were evenly scattered across the entire area, and both fresh and old cattle dung was common within the swale boundary. We counted 47 cattle, grazing and loafing in and around the swale. Vegetation cover in the swale was generally greater than $90 \%$, except in the cow trails where bare soil was exposed. Associated species were Hordeum murinum, Vulpia spp., Distichlis spicata var. stolonifera, Frankenia salina, Erodium moschatum, Salicornia virginica, Medicago polymorpha, Malva parviflora, and Sonchus oleraceus.

Lasthenia glabrata ssp. coulteri was generally confined to the saturated clay loam soils of the swale, abruptly disappearing from the community where drier soils, greater Distichlis spicata var. stolonifera cover, and thicker grass thatch prevailed. The 
population consisted of sparsely scattered single individuals growing between dense patches of other plants. A total of 922 plants was counted in $175 \mathrm{~m}^{2}$ of belt transect area. Mean plant density per transect ranged from 0 to 19.4 plants $/ \mathrm{m}^{2}$. Mean density for the population was $5.18 \pm 7.85 \mathrm{plants} / \mathrm{m}^{2}$; median density was $1.31 \mathrm{plants} / \mathrm{m}^{2}$. Mean plant height $(\mathrm{n}=11)$ was $9.18 \pm 1.72 \mathrm{~cm}$. Despite the abundance of hoof prints, only $1 \%$ of plants were obviously trampled and damaged by cattle. Plants were generally not present in hoof prints, indicating that rather than damaging existing plants, the effects of cattle trampling may be to curtail seedling emergence. An index of cow trails was derived for comparisons to future years by calculating the proportion of plots crossed by trails: Index of trailing = \# trails crossing plots/\# plots sampled. This index was 0.11 for the March 30, 1996 samples. Insects had damaged the ray or disk flowers, or both, by feeding on an additional $1 \%$ of plants seen.

Reproductive biology.

Lasthenia glabrata ssp. coulteri is an early spring-flowering, self-incompatible annual with bisexual disk and pistillate ray flowers (Ornduff 1966). Plants seen during the 1996 census were developing seeds.

\section{Lilium humboldtii Roezl \& Leichtlin ssp. ocellatum(Kellogg) Thorne locellated Humboldt} lily). Liliaceae

Lilium humboldtii ssp. ocellatum, a cormaceous to rhizomatous perennial herb, occurs on the mainland coast from southern Oregon to northern Baja, and on Anacapa, Santa Cruz, and Santa Rosa islands (Munz and Keck 1963; Munz 1974; Junak et al. 1995). Its ecological distribution on the islands has been described as coastal bluffs, shaded north-facing slopes, and creek banks in association with chaparral, coastal scrub, oak woodland, and pine forest communities (Munz 1974; Skinner, 1988, 1993; Junak et al. 1995).

\section{Ground surveys.}

Lilium humboldtii ssp. ocellatum is known to have existed on Santa Rosa Island in the past (R. Philbrick, pers. comm., S. Junak, pers. comm.), but no specific collection records or field observation notes are available to determine where populations occurred. We searched approximately $85 \%$ of potential habitats on Santa Rosa, and found one population of eight plants. The plants were growing on a vertical stream bank sheltered from above by an overhanging rock outcrop. Two of the plants were browsed off at approximately $1.5 \mathrm{~m}$, three of the remaining six plants were flowering or producing buds in May 1996. 
We surveyed 13 populations on Santa Cruz Island. Population size among the 13 sites ranged from 3 to 68 plants $($ mean $=20 \pm 5$, median $=17$ ). Most populations occurred on rocky, often deep, soils of steep, north-facing slopes and canyons at elevations between 30 and $440 \mathrm{~m}$. Although pig trails and evidence of rooting were observed in the areas of most populations, most sites were characterized by steep slopes and dense woody vegetation, which appear to deter encroachment. Substrates were derived from either metamorphic or volcanic rocks. Most sites were generally characterized by dense vegetation with cover exceeding $90 \%$. The most common associates included Arctostaphylos tomentosa, Ceanothus arboreus, Heteromeles arbutifolia, Lyonothamnus floribundus ssp. asplenifolius, Pinus muricata, Quercus agrifolia, and Vaccinium ovatum, which are characteristic of insular pine forest, oak woodland, and chaparral communities (Philbrick and Haller 1977; Bjorndalen 1978). No seedlings were observed. Most populations consisted of reproductive plants, but in several populations, some plants produced only short leafy shoots, suggesting that they had not reached reproductive maturity.

\section{Reproductive Biology.}

Lilium humboldtii ssp. ocellatum is a herbaceous perennial, usually bearing a single, leafy shoot terminating in an inflorescence. Reproductive plants range from 0.9 to 2 meters tall. Flowers are bisexual, radial, and composed of six large, orange-yellow perianth parts, with many purple spots, six stamens, and one pistil. Although hummingbirds were observed visiting the flowers in several populations on Santa Cruz Island, butterflies have been reported as much more effective pollinators in mainland populations (Skinner 1988).

Reproductive biology was assessed by estimating the number of flowers and fruits per plant in six and five populations in May and July 1996, respectively, on Santa Cruz Island (Stanton, Centinela, Embudo 1, Embudo 2 (flowers only), Puerto 1, and Puerto 2). The number of plants at each site ranged from 12 to 22 . The number of flowers per stem were counted in May 1996. Five populations were revisited in July to assess fruit and seed production. The numbers of seeds per fruit were estimated from a random sample of 10 fruits in each population.

Mean flower production in each of the populations was $11.2 \pm 1.2(\mathrm{n}=17)$ at Stanton $(n=17), 12.5 \pm 0.9$ at Centinela $(n=20), 9.3 \pm 0.6$ at Embudo $1(n=22), 10.0 \pm$ 0.6 at Embudo $2(n=17), 13.0 \pm 1.3$ at Puerto $1(n=12)$, and $14.1 \pm 0.9$ at Puerto $2(n=$ 14). Mean fruit production in five populations was $6.3 \pm 1.0$ at Stanton $(n=17), 8.1 \pm 1.0$ at Centinela $(n=20), 6.3 \pm 0.9$ at Embudo $1(n=22), 9.1 \pm 0.9$ at Puerto $1(n=12)$, and $6.7 \pm 1.4$ at Puerto $2(n=14)$. The mean number of seeds per fruit $(n=10$ fruits per site) was $67.4 \pm 6.9$ at Stanton, $36.3 \pm 8.1$ at Centinela, 54.6 \pm 7.7 at Embudo 1, 57.3 \pm 10.7 at Puerto 1 , and $46.7 \pm 6.7$ at Puerto 2 . 
Self-compatibility was estimated from number of seeds per fruit obtained from controlled crosses performed on four plants at the Santa Barbara Botanic Garden. Selfcompatibility was estimated by pollinating five flowers on each plant, using pollen from the same flower or flowers on the same plant. Cross-compatibility was estimated by pollinating five flowers on each plant, using pollen derived from separate plants. Flowers were bagged with nylon mesh to exclude insect visitation. To estimate the level of self-pollination, five flowers on each of the same plants were covered with nylon mesh to exclude pollinators, but without hand-pollination. Flowers were randomized with respect to each of the three treatments to avoid potential position effects.

No significant differences were found among plants for self-pollination (ANOVA: $\mathrm{p}=0.32$, among $\mathrm{ms}=4.60$, within $\mathrm{ms}=3.65, \mathrm{df}=3$ ), out-crossed flowers (ANOVA: $\mathrm{p}=0.32$, among $\mathrm{ms}=4.60$, within $\mathrm{ms}=2.65, \mathrm{df}=3$ ), or unmanipulated flowers (ANOVA: $\mathrm{p}=0.95$, among $\mathrm{ms}=4.85$, within $\mathrm{ms}=40.58, \mathrm{df}=3$ ). The overall mean number of seeds per fruit derived from self-pollination was $50.8 \pm 5.5(n=20)$; the mean number of seeds per fruit from out-crossed flowers was $46.7 \pm 5.0(n=20)$. The mean number of seeds per fruit in unmanipulated flowers was $6.7 \pm 1.3(n=20)$. Insignificant differences between selfed versus out-crossed flowers $(50.8 \pm 5.5$ versus $46.7 \pm 5.0$ ) show that Lilium humboldtii ssp. ocellatum is self-compatible. However, the low levels of seed production in bagged, unmanipulated flowers (mean $=6.7$ ) suggests that fruit and seed production is enhanced by pollinator visitation.

\section{Orobanche parishii (Jeps.) Heckard ssp. brachyloba Heckard (short-lobed broom-rape) Orobanchaceae}

Orobanche parishii ssp. brachyloba, a parasitic perennial herb, occurs on the mainland coast from San Luis Obispo County south to northern Baja California, and on Santa Catalina, San Nicolas, Santa Cruz, Santa Rosa, and San Miguel islands (Heckard 1973; Junak et al. 1995). Its ecological distribution has been described as occurring on coastal flats, south-facing talus slopes, ridgetops, and floodplains, in association with coastal strand or scrub communities (Munz 1974; Heckard 1973, 1993; Junak et al. 1995).

\section{Ground surveys.}

Orobanche parishii ssp. brachyloba was known from 1930 and 1977 collections made in two separate locations on Santa Rosa Island. We found extensive populations of more than a thousand plants at both of those locations in 1995. Two additional undocu-mented populations of 50-100 plants had been located in 1994 surveys. Individual plant density was counted in plots at the Sandy Point population in September 1995 (see below). 
Population size among the four sites ranged from 3 to 48 plants (mean $=25 \pm 9$, median $=26$ ). Three of the four populations occurred on stabilized sand dunes at elevations between 5 and $10 \mathrm{~m}$. The most common associates included Abronia maritima, Ambrosia chamissonis, Atriplex semibaccata, Atriplex leucophylla, and Isocoma menziesii, which are characteristic of insular coastal strand communities (Philbrick and Haller 1977). A fourth population, consisting of only three plants, was found on sandy soil at an elevation of $250 \mathrm{~m}$. The most common associates included Artemisia californica, Lessingia filaginifolia, and Cardionema ramosissimum, which are characteristic of coastal sage scrub communities (Philbrick and Haller 1977; Minnich 1980).

\section{Population census.}

Density was estimated in two contrasting habitats on Santa Rosa Island, October 11-12, 1995. The first was a scattered population sprawling over several hectares of low dune ridges at about $12 \mathrm{~m}$ elevation near Jaw Gulch, and the second population occupied a similar area on sandy uplands above the coastal bluff at Sandy Point at 100-120 m elevation. Associated species at both sites included Isocoma menziesii, Atriplex californica, Astragalus miguelensis, and Distichlis spicata. The lower terrace site included additional dune taxa, such as Camissonia che iranthifolia and Ambrosia chamissonis, while the upland site had less shrub cover and additional species characteristic of annual Mediterranean grassland on stabilized dunes.

The population area at each location was delineated by walking the site and finding population boundaries. Each population was then subdivided into three approximately equal areas, and one $4 \times 50 \mathrm{~m}$ belt transect was randomly located within each area. Numbers of $O$. parishii ssp. brachyloba rooted within each belt were counted in $10-\mathrm{m}$ transect segments.

Table 10 shows plant density data summarized by site and by transect. A total of 237 plants was counted in transects at the lower Jaw Gulch population, and 118 plants occurred in transects on top of Sandy Point. The mean number of plants per square meter was approximately twice as high on the lower terrace as on the sandy upland. Vegetation on the lower terrace was generally more open and included a greater density of shrubs than the uplands. Although Isocoma menziesii appears to be the primary host plant, future sampling is needed to determine host plant relationships. It is possible that the greater grass density and the lower Isocoma density of the uplands limit $O$. parishii ssp. brachyloba density in the upland site. 
Table 10. Orobanche parishü ssp.brachyloba density, October 11-12, 1995.

\begin{tabular}{||ccc||}
\hline $\begin{array}{c}\text { Lower terrace at Jaw } \\
\text { Gulch }\end{array}$ & Plants $/ \mathrm{m}^{2}$ & Census count \\
\hline Transect 1 & & 37 \\
Transect 2 & 0.185 & 129 \\
Transect 3 & 0.645 & 71 \\
Upper terrace at Sandy & 0.355 & \\
Point & & 16 \\
Transect 1 & & 39 \\
Transect 2 & 0.080 & 63 \\
Transect 3 & 0.195 & \\
\hline
\end{tabular}

Reproductive Biology.

Orobanche parishii ssp. brachyloba is a herbaceous parasite with a dense, fleshy spike. On Santa Cruz Island, the most common host plant is Isocoma menziesii (Junak et al. 1995). Reproductive plants range from 5 to $12 \mathrm{~cm}$ tall. Flowers are bisexual, bilateral, and are composed of five fused petals, four stamens, and one pistil.

Reproductive biology in natural populations was assessed by estimating the number of flowers per plant in two populations on Santa Cruz Island (Sauces, Christy). In both populations, we counted the number of flowers on each of 20 plants. Random samples of 20 fruits per population were used to assess the number of seeds per fruit.

We found no significant differences between the two populations for flower number (ANOVA: $\mathrm{p}=0.36$, between $\mathrm{ms}=0.61$, within $\mathrm{ms}=0.71, \mathrm{df}=1,38$ ) and seeds per flower $(p=0.31$, between $\mathrm{ms}=2.33$, within $\mathrm{ms}=2.18, \mathrm{df}=1,38)$. The mean number of flowers per plant was 17.2 $\pm 1.1(n=40)$. The overall mean number of seeds per fruit was $46.5 \pm 3.1(n=40)$. 


\section{GENERAL SUMMARY}

About one-third of the rare plant observations we found in archive searches and compiled into a rare plants database for the northern Channel Islands provided geograhic locations specific enough for population relocation. Most of the relocatable occurrences were known from collections made prior to 1960 , that had been visited several times in subsequent decades by other botanists. Consequently, there are several records in the rare plants database for each of these population occurrences, allowing us to verify that particular populations persisted over several decades. However, less than $10 \%$ of these historic observations include any notes on population size or condition, so we are unable to make inferences about trends in population growth rates from the historic information. Generally, most populations that were known before 1950 remain today. They now range in size from less than five to several hundred individuals each; in several cases, populations covering large areas include nearly a thousand individuals. Whether any populations have good chances for long-term viability depends on the growth forms, life histories and reproductive strategies of the taxa, the vigor of the individuals and the degree of population isolation from other pollen and seed sources.

Most of the known occurrences of rare plants on Santa Rosa Island were within several hours' hiking distance of Beecher's Bay. We searched approximately $80 \%$ of the potential rare plant habitats on the entire island for undocumented occurrences of fourteen candidate and proposed endangered taxa, and found new sites for eight of them. Most new finds were in areas not easily accessible on foot, either because they were far from typical boat landings, or were in steep canyon or bluff terrain. They generally consisted of less than several hundred plants, but did not appear to be newly established populations. Most likely they have been in existence for many years, but remained undocumented because of inaccessibility. Because the flora of Santa Cruz has been much better studied, our focus there was to revisit known sites, rather than to search out new occurrences. Nevertheless, we documented new occurrences of five taxa, in sites probably not frequently visited by botanists in the past. We did not systematically resurvey Anacapa, San Miguel or Santa Barbara Islands with this funding.

Habitat conditions on Santa Rosa and Santa Cruz Islands show the effects of long-term grazing land use. Soils are eroded and compacted, trailing is evident, and root systems are exposed on the steep slopes. Ungulate use continues on Santa Rosa Island, and effects on rare plant habitats are most pronounced in stream bottoms, on steep slopes, and in shrubby and woodland vegetation. Effects on populations are variable, including apparent loss of portions of populations; undermining of root systems, toppling of plants and loss of vigor; and lack of soil structure, litter, and duff that would allow for vegetative regeneration, seedling recruitment, or seed bank retention. Most woody perennials had growth forms indicative of historic browsing. Stem tips, flowers and fruits of both woody and herbaceous plants on Santa Rosa are still browsed. Most populations on both islands were lacking small individuals, indicating that recruitment has not occurred in recent years.

Populations of Atriplex pacifica, Dudleya candelabrum, Erysimum ammophilum, and Lilium humboldtii ssp. ocellatum were so small and confined to discrete habitat 
patches that it was possible to count the individuals present. Population sizes ranged from six individuals ( $E$. ammophilum on Santa Rosa) to 505 individuals (D. candelabrum on Santa Rosa) each. Additionally, there are very few known populations of these taxa on one or both islands; they are at risk of extirpation as a consequence of their isolation and small size.

We conducted density sampling of six taxa with either widespread distributions or large numbers of individuals in smaller, localized areas. Castilleja mollis and Orobanche parishii ssp. brachyloba are scattered with densities of less that one plant per square meter over tens of acres on coastal terraces and bluffs. Jepsonia malvifolia is also widespread in patches of locally high density throughout chaparral and the Torrey pines on Santa Rosa, but is confined to less than a dozen small grassy openings in chaparral on Santa Cruz island. The density data, and later demography sampling in which we followed the development of tagged individuals in permanent plots, showed that both $C$. mollis and $J$. malvifolia are threatened by feral animals. A significant source of $C$. mollis mortality was hoof scraping by deer and elk during the fall breeding season on Santa Rosa, while J. malvifolia plants were dug up and killed by pigs on Santa Cruz. Further geographic spread of all three of these taxa is limited by habitat availability. Additionally, distributions of $C$. mollis and $O$. parishii ssp. brachyloba are limited by host plant availability. The remaining two taxa sampled, Erysimum insulare ssp. insulare and Lasthenia glabrata ssp. coulteri, occur as a few localized populations occupying less than one hectare, with densities of 4 and 5 plants per square meter, respectively. We could find only three $E$. insulare ssp. insulare populations on Santa Rosa, and one $L$. glabrata ssp. coulteri occurrence. Other populations of both these taxa may have been extirpated on Santa Rosa; we could not find plants in additional reliable historic locations.

The remaining five taxa are widely scattered in fairly large numbers on one or both islands. They occurred in clusters of individuals on steep slopes and canyon walls, generally above the reach of ungulates. Arctostaphylos confertiflora and Dendromecon rigida ssp. harfordii are scattered in isolated groves of one to several plants each. Most individuals had roots exposed by erosion and mushroomed or multi-stemmed growth forms reflecting the effects of past and current browsing and soil erosion. Eriogonum grande var. rubescens and Heuchera maxima were widespread in clumps of several to many plants each, throughout their potential habitats on both islands. We found several dozen new populations of both species. Both were producing flowers and seed, although the $E$. grande var. rubescens on Santa Rosa was heavily browsed by deer.

Helianthemem greenei was known from one location on Santa Rosa, and one on Santa Cruz. We could not find it in repeated searches on Santa Rosa, either in the previously documented location or in similar potential habitats. By contrast, new populations of three to 1000 plants were found on Santa Cruz in areas that were burned in 1994. These were new populations, establishing in response to the fires. Densities within these populations ranged from 4 to 12 plants per square meter in 1996.

The density data show that populations of the woody perennials are skewed toward the larger individuals, indicating a lack of recruitment in recent years. In addition to poor habitat conditions and continuing predation, recruitment into existing populations and establishment of new populations of the fourteen species may be limited by their reproductive biology in several ways. Dendromecon rigida ssp. harfordii and Jepsonia 
malvifolia appear to be self-incompatible. Thus, seed production in small populations may become limited by the number of genotypes determining self-incompatibility and also, in the case of the heterostylous $J$. malvifolia, by the presence of both floral forms. The long-term success of Dendromecon populations also may be limited by the absence of fire and dispersal by seed-harvesting ants.

Four other species (Dudleya candelabrum, Eriogonum grande var. rubescens, Heuchera maxima, and Lilium humboldtii ssp. ocellatum) are apparently selfcompatible, but fruit and seed production appears limited in natural populations by the level of natural pollination. Three species (D. candelabrum, H. maxima, and $L$. humboldtii ssp. ocellatum) have fruit and seed production that approach expectations, based on experimental pollinations, although each is limited by natural pollination to some degree. In $L$. humboldtii ssp. ocellatum, optimal fruit and seed production also may be limited by the type of pollinator (butterflies versus hummingbirds). In $E$. grande var. rubescens, the maximum number of flowers producing seeds is only $12.7 \%$, suggesting that other intrinsic factors may be involved.

Fruit and seed production in the self-compatible, strongly self-pollinating Atriplex pacifica and Helianthemum greenei are apparently not limited by intrinsic factors. Both show high levels of fruit and seed production under natural conditions. However, population size in $H$. greenei is clearly limited by the periodicity of fires, which appears critical to recruitment and establishment. Although the parasitic Orobanche parishii ssp. brachyloba has high levels of fruit and seed production under natural conditions, recruitment and establishment is limited by the distribution of a suitable host species, Isocoma menziesii.

In summary, a new GIS-linked database containing nearly 1500 historic and current observations of the rare and sensitive plants of the five northern islands was created for the long-term ecological monitoring program at Channel Islands National Park. We used the database to guide ground surveys of nearly $80 \%$ of known and potential habitats on Santa Rosa, and relocate about $20 \%$ of populations on Santa Cruz Island. We were able to relocate a majority of reliable historic occurrences of the fourteen taxa studied with this NBS and NPS funding, and we found new occurrences of nine of them. Habitat conditions were generally degraded by sustained grazing over the past century, and the growth forms of long-lived woody plants indicated past browsing. The browsing continues on Santa Rosa Island, on plants growing in locations accessible by deer. Population surveys and quantitative sampling show that seedling recruitment has not occurred in recent years, except in Jepsonia malvifolia on Santa Rosa Island. Recruitment is apparently limited by poor soil conditions, loss of soil seed banks, lack of fire, failure to mature seeds because of continued browsing (Santa Rosa) and rooting (Santa Cruz), self-incompatibility, population isolation, and low densities of host plants or pollinators. Six taxa have so few populations, or populations that are so small and isolated, that they appear to be in danger of extirpation. Two taxa have many more Santa Rosa Island occurrences than were previously documented, reflecting the lack of earlier systematic botanical surveys. Our research indicates that populations of these fourteen rare taxa remain on both islands. Although they appear scattered and in poor condition, they provide the stock for regeneration as ecological conditions improve with time and focused restoration efforts. 


\section{LITERATURE CITED}

Bartel, J. 1993. Dudleya pp. 525-530. In Hickman, J. (ed.) The Jepson Manual: higher plants of California. University of California Press, Berkeley.

Berg, N. 1966. Seed dispersal of Dendromecon: its ecologic, evolutionary, and taxonomic significance. American Journal of Botany 53: 61-73.

Bjorndalen, J. 1978. The chaparral vegetation of Santa Cruz Island, California. Norwegian Journal of Botany 25: 255-269.

Bullock, S. 1974. Seed dispersal of Dendromecon by the seed predator Pogonomyrmex. Madroño 22: 378-379.

Clark, C. 1993. Papaveraceae. pp. 810-816. In Hickman, J. (ed.) The Jepson Manual: higher plants of California. University of California Press, Berkeley.

Daoud, H. and R. Wilbur. 1965. A revision of the North American species of Helianthemum (Cistaceae). Rhodora 67: 63-82, 201-216, 255-312.

Elvander, P. 1993. Saxifragaceae. pp. 1002-1011. In Hickman, J. (ed.) The Jepson Manual: higher plants of California. University of California Press, Berkeley.

Hall, H. and F. Clements. 1923. The phylogenetic method in taxonomy. The North American species of Artemisia, Chrysothamnus, and Atriplex. Carnegie Institution of Washington, Publication No. 326, Washington, DC.

Heckard, L. 1973. A taxonomic revision of the Orobanche californica complex. Madroño 22: 41-70.

Heckard, L. 1993. Orobanchaceae. pp. 804-808. In Hickman, J. (ed.) The Jepson Manual: higher plants of California. University of California Press, Berkeley.

Heckard, L., S. Ingram, and T. Chuang. 1991. Status and distribution of Castilleja mollis. Madroño 38: 141-142.

Hochberg, M, S. Junak, and R. Philbrick. 1980. Botanical study of Santa Cruz Island. Volumes 1-3. 1-100 pp., plus 45 maps. Unpublished report to The Nature Conservancy.

Hoover, R.F. 1970. Flora of San Luis Obispo County. University of California Press, Los Angeles, $\mathrm{Ca}$.

Ingram, S.W. 1990. An examination of Castilleja mollis and its distribution. Report prepared for The Nature Conservancy, Nipomo Dunes Preserve, Central Coast and Valley Office, San Luis Obispo, Ca. 
Junak, S., T. Ayers, R. Scott, D. Wilken, and D. Young. 1995. A flora of Santa Cruz Island. Santa Barbara Botanic Garden and the California Native Plant Society.

McClintock, E. 1993. Cistaceae. pp. 515-516. In Hickman, J. (ed.) The Jepson Manual: higher plants of California. University of California Press, Berkeley.

McMinn, H. 1964. An illustrated manual of California shrubs. University of California Press, Berkeley.

Minnich, R. 1980. Vegetation of Santa Cruz and Santa Catalina islands. pp. 123-127. In D. Powers (ed.) The California islands: proceedings of a multidisciplinary symposium. Santa Barbara Museum of Natural History, Santa Barbara, California.

Moran, R. 1951. A revision of Dudleya (Crassulaceae). Ph.D. dissertation, University of California, Berkeley. 295 pp.

Munz, P. 1974. A flora of southern California. University of California Press, Berkeley.

Munz, P. and D. Keck 1963. A California Flora. University of California Press, Berkeley.

Neal, D. 1974. Dendromecon rigida Benth., stiff bushpoppy. p 372. In C. Schopmeyer (ed.) Seeds of woody plants in the United States. USDA Forest Service, Agriculture Handbook No. 450.

Ornduff, R. 1961. Heterostyly in Jepsonia (Saxifragaceae). Recent Advances in Botany 1: 885-887.

Ornduff, R. 1966. A biosystematic survey of the goldfield genus Lasthenia. University of California Publ. Botany 40: 1-92.

Ornduff, R. 1969. Ecology, morphology, and systematics of Jepsonia (Saxifragaceae). Brittonia 21: 286-296.

Ornduff, R. 1970. Heteromorphic incompatibility in Jepsonia malvifolia. Bulletin of the Torrey Botanical Club 97: 258-261.

Philbrick, R. and J. Haller. 1977. The southern California islands. pp. 893-906. In M. Barbour and J. Major (eds.) Terrestrial vegetation of California. John Wiley and Sons, New York.

Price, R. 1993. Erysimum. pp. 421-422. In Hickman, J. (ed.) The Jepson Manual: higher plants of California. University of California Press, Berkeley.

Proctor, M., P. Yeo, and A. Lack. 1996. The natural history of pollination. Timber Press, Portland, OR. 479 pp.

Reveal, J. 1989. The Eriogonoid flora of California (Polygonaceae:

Eriogonoideae). Phytologia 66: 295-414. 
Skinner, M. 1988. Comparative pollination ecology and floral evolution in Pacific coast Lilium. Ph.D. dissertation. Harvard University, Cambridge, MA. 475 pp.

Skinner, M. 1993. Lilium. pp. 1198-1200. In Hickman, J. (ed.) The Jepson Manual: higher plants of California. University of California Press, Berkeley.

Skinner, M. and B. Pavlik (eds.) 1984. Inventory of rare and endangered vascular plants of California. California Native Plant Society, Sacramento. 338 pp.

Taylor, D. and D. Wilken. 1993. Atriplex. pp. 501-505. In Hickman, J. (ed.) The Jepson Manual: higher plants of California. University of California Press, Berkeley.

U.S. Fish and Wildlife Service. 1995. Proposed rule for 16 plant taxa from the northern Channel Islands, California. Federal Register, vol. 60, No. 142.

Wells. P. 1993. Arctostaphylos. pp. 545-559. In Hickman, J. (ed.) The Jepson Manual: higher plants of California. University of California Press, Berkeley.

Westman, W. 1983. Island biogeography: studies on the xeric shrublands of the inner Channel Islands, California. Journal of Biogeography 10: 97-118. 